\title{
PGE AND Ag MINERALIZATION IN A BRECCIA ZONE OF THE PRECAMBRIAN NUASAHI ULTRAMAFIC-MAFIC COMPLEX, ORISSA, INDIA
}

\author{
SISIR K. MONDAL ${ }^{\S}$ AND TAPAN K. BAIDYA \\ Department of Geological Sciences, Jadavpur University, Calcutta 700032, India
}

KOLAR N. GURURAJA RAO

\#1450, C/D Block, Kuvempunagar P.O., Mysore, Karnataka 570023, India

MICHAEL D. GLASCOCK ${ }^{\S}$

Research Reactor Center, University of Missouri, Columbia, Missouri 65211, U.S.A.

\begin{abstract}
The Nuasahi ultramafic-mafic complex, in Orissa, India, contains high concentrations of platinum-group elements (Pt up to $9.6 \mathrm{ppm}, \mathrm{Pd}$ up to $17.9 \mathrm{ppm}$ ) and $\mathrm{Ag}$ (up to $6.6 \mathrm{ppm}$ ) in a chromiferous sulfide-rich breccia zone. The plutonic complex occurs within an Archean belt of supracrustal rocks. The complex consists of an ultramafic unit in fault contact with and overlain by gabbros whose stratigraphic top is characterized by a zone of brecciation. Lode chromite deposits occur in the ultramafic suite and are currently being mined. Magnesiochromite compositions in the lodes are refractory and show little variation within the ultramafic suite $\left(\mathrm{Cr}_{2} \mathrm{O}_{3} \sim 60 \%, \mathrm{Al}_{2} \mathrm{O}_{3} \sim 12 \%, \mathrm{MgO} \sim 15 \%\right)$. Sudburyite, (Pd,Bi)Sb, members of the michenerite-testibiopalladite series, and irarsite-hollingworthite (IrAsS-RhAsS) are the common platinum-group minerals (PGM) in the chromite-sulfide assemblage of the breccia zone. Sudburyite is preferentially included within coarse-grained ferrian chromite, along with numerous inclusions of chalcopyrite, pyrrhotite, rutile, ilmenite and oriented lamellae of clinochlore. The distinctive noble-metal composition (high $\mathrm{Pd}, \mathrm{Pt}$ and $\mathrm{Ag}$ with high $\mathrm{Cu}$ ) and dominant $\mathrm{Pd}-\mathrm{Bi}-\mathrm{Te}-\mathrm{Sb}$-bearing PGM in the mineralized portion indicate its evolved nature. Mineralization developed by magmatic processes; a hybrid magma resulting from partial incorporation of serpentinized chromite-bearing ultramafic rocks and chromitite in the younger gabbroic magma was emplaced within the preexisting breccia zone. The breccia zone developed during brittle deformation along a NNW-trending shear zone.
\end{abstract}

Keywords: ultramafic complex, breccia zone, chromite, sulfides, platinum-group element mineralization, inclusions, platinumgroup minerals, Nuasahi, Orissa, India.

\section{SOMMAIRE}

Le complexe ultramafique-mafique de Nuasahi, à Orissa, en Inde, contient des concentrations élevées des éléments du groupe du platine (juqu'à 9.6 ppm de Pt, 17.9 ppm de Pd) et d'argent (jusqu'à 6.6 ppm) dans une zone brécifiée enrichie en spinelle chromifère et en sulfures. Le complexe plutonique est situé dans une ceinture de roches archéennes d'origine supracrustale. Il contient une unité ultramafique en contact tectonique avec une unité supérieure gabbroïque dont le sommet est bréchifié. Les gisements in situ de spinelle chromifère se trouvent dans la suite ultramafique, et sont présentement exploités. La composition de la magnésiochromite est réfractaire et varie peu dans la suite ultramafique $\left(\mathrm{Cr}_{2} \mathrm{O}_{3} \sim 60 \%, \mathrm{Al}_{2} \mathrm{O}_{3} \sim 12 \%, \mathrm{MgO} \sim 15 \%\right)$. Parmi les minéraux du groupe du platine, on trouve sudburyite $(\mathrm{Pd}, \mathrm{Bi}) \mathrm{Sb}$, des membres de la série michenerite-testibiopalladite, et irarsitehollingworthite (IrAsS-RhAsS) associés au spinelle chromifère et aux sulfures de la zone bréchifiée. La sudburyite se présente surtout en inclusions dans la chromite ferrique à grains grossiers, de même que chalcopyrite, pyrrhotite, rutile, ilménite, et clinochlore en lamelles orientées. L'enrichissement distinctif en métaux nobles (Pd, Pd, Pt et Ag avec Cu élevé) et la dominance de minéraux du groupe du platine enrichis en $\mathrm{Pd}-\mathrm{Bi}-\mathrm{Te}-\mathrm{Sb}$ témoignent du degré d'évolution de la partie minéralisée. Les processus de minéralisation se sont dévelopés au stade magmatique; un magma hybride, résultat de l'incorporation de blocs ultramafiques chromifères serpentinisés et de chromitite dans le magma gabbrö̈que, a recoupé la zone bréchifiée. Celle-ci s'est développé au cours d'un épisode de déformation cassante le long d'une zone de cisaillement orientée nord-nord-ouest.

(Traduit par la Rédaction)

Mots-clés: complexe ultramafique, zone bréchifiée, chromite, sulfures, minéralisation en éléments du groupe du platine, inclusions, minéraux du groupe du platine, Nuasahi, Orissa, Inde.

§E-mail addresses: sisirm@rediffmail.com, glascockm@missouri.edu 


\section{INTRODUCTION}

The Nuasahi ultramafic-mafic complex $\left(21^{\circ} 16^{\prime} \mathrm{N}\right.$, $86^{\circ} 20^{\prime} \mathrm{E}$ ), located in the southeastern part of the Singhbhum craton in the eastern Indian Shield, contains one of the largest chromite deposits in India. Earlier investigators concentrated mainly on petrological, chemical and genetic aspects of chromite mineralization (e.g., Chakraborty 1958, Deb \& Chakraborty 1960, Mukherjee 1962, Haldar 1967, Varma 1964, Mohanty $\&$ Sahoo 1989). The Nuasahi chromite deposit was described as fissure-filling type, and the whole complex was taken to represent a continuous series of ultramafic and mafic rocks produced by fractional crystallization of a mafic magma (Chakraborty 1958, Deb \& Chakraborty 1960). As an alternative hypothesis, the chromite orebodies were attributed to hydrothermal solutions issued from an ultrabasic magma, the complex representing a highly differentiated suite of the Alpine type of ultramafic complex (Varma 1964). Haldar
(1967) documented the discordant relation between ultramafic and mafic suite of rocks in this complex. Mondal \& Baidya (1997) first reported the occurrence of platinum-group minerals (PGM) in a tectonic breccia zone in the eastern part of the complex and described the petrographic as well as field aspects of the sulfidebearing zone. In this paper, we provide further details of our mineralogical observations and preliminary geochemical data on the sulfide-rich zone, and investigate the origin of the mineralization.

\section{Geological Setting of the Complex}

The oldest rocks in the area belong to Iron Ore Group (IOG) (Fig. 1). Saha et al. (1988) considered the age of sedimentation of the IOG in the eastern Indian Shield to be between 3300 and $3100 \mathrm{Ma}$ (Sm-Nd whole-rock isochron). At Nuasahi, the IOG rocks are considered to have been intruded by the ultramafic-mafic plutonic complex at about 2200-2100 Ma (Saha 1994), but pre-

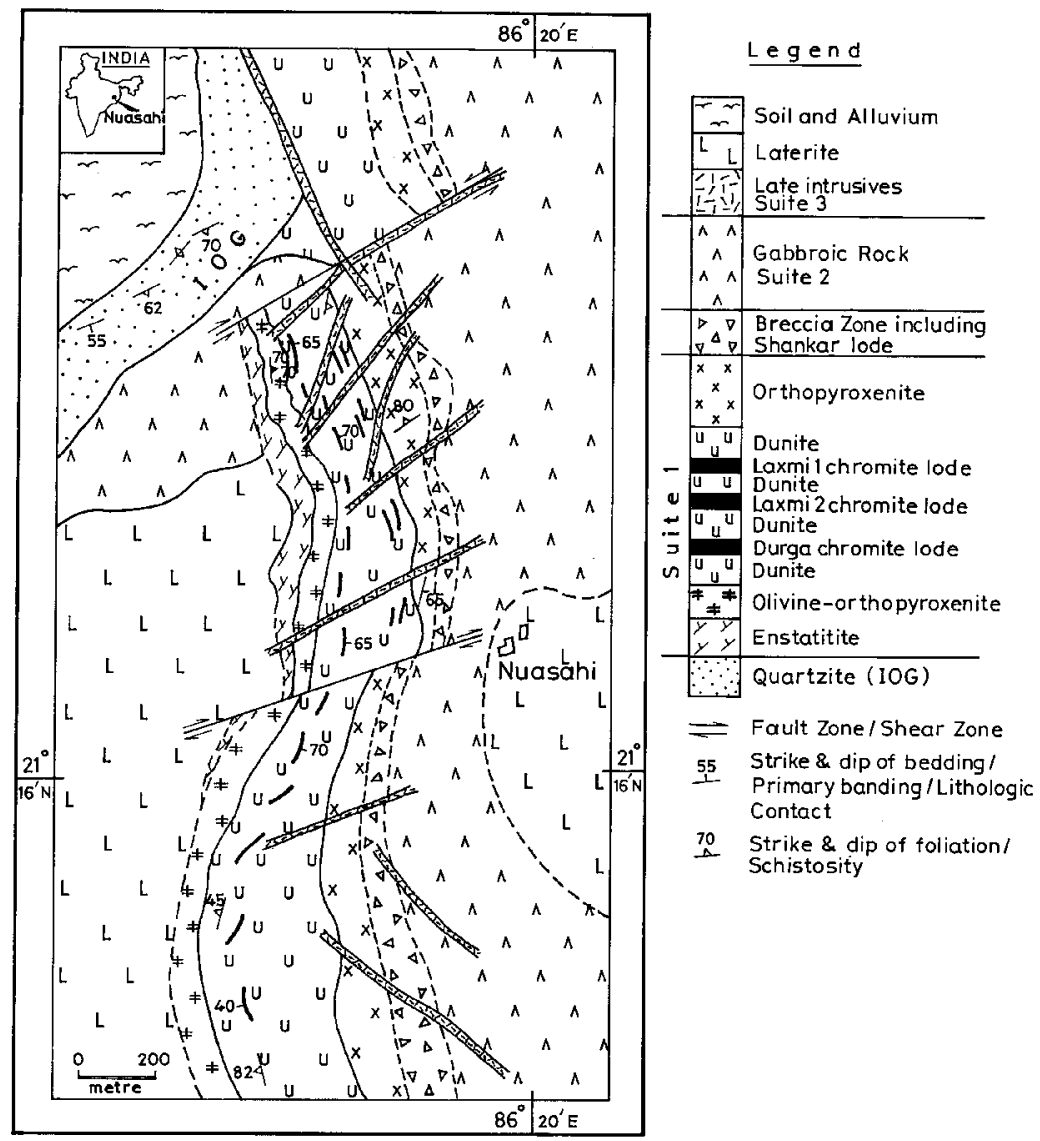

FIG. 1. Geological map of the Nuasahi chromite belt, Orissa, India. 

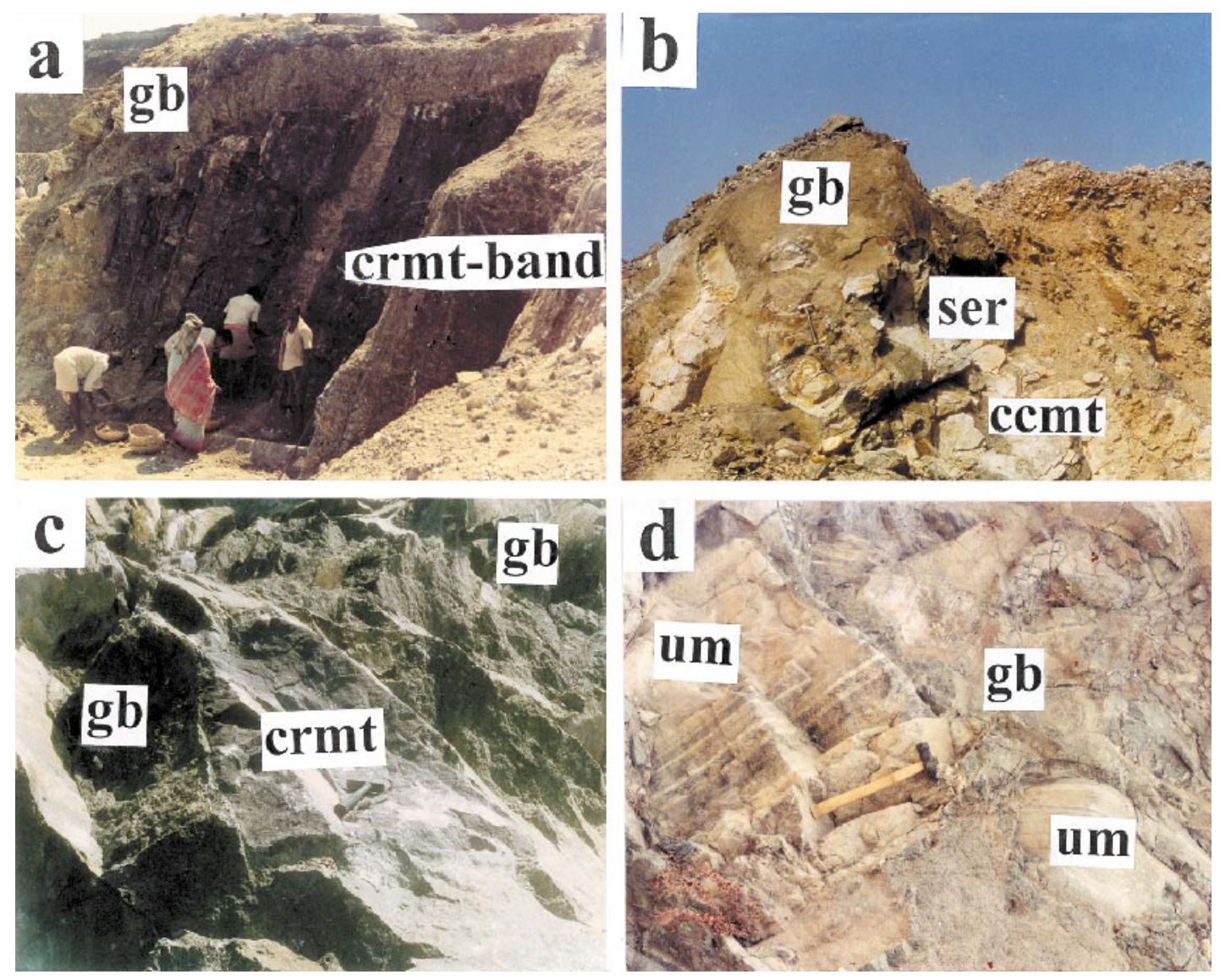

FIG. 2. Field photographs of Breccia Zone, Nuasahi ultramafic-mafic Complex, Orissa, India. (a) Large bands of chromitite (crmt-band) are intruded by gabbroic material ( $\mathrm{gb}$ ). (b) Differently oriented fragments of serpentinite and chromitite (ser, crmt) enclosed within gabbroic material (gb) in the Breccia Zone. (c) A triangular fragment of massive chromitite (crmt) of the Shankar lode enclosed within sulfide-rich gabbroic rock (gb) in hanging-wall of the Breccia Zone. (d) Fragments of banded ultramafic rock (um) within the gabbroic matrix ( $\mathrm{gb}$ ) of the Breccia Zone.

cise age dating has not yet been done. The plutonic complex contains three magmatic suites (Fig. 1). Suite 1 consists of an interlayered sequence of chromian-spinelbearing ultramafic rocks, suite 2 contains gabbroic rocks with bands of titaniferous magnetite, and suite 3 groups later intrusive phases of diabase, clinopyroxenite, pegmatitic gabbro and quartz diorite. The chromian-spinelbearing ultramafic rocks of the first suite are exposed in an area $\sim 5 \mathrm{~km}$ in length and $\sim 400 \mathrm{~m}$ in width, having a general NNW-SSE trend. Igneous layering in these rocks generally dips $60-70^{\circ} \mathrm{E}$. The various lithological units of the first suite are enstatitite ( $>95$ vol.\% enstatite), olivine orthopyroxenite, dunite, orthopyroxenite and chromitite. Gabbroic rocks of suite 2 are typically massive but contain a band $\sim 1-2 \mathrm{~m}$ thick of titaniferous magnetite at the eastern end of the complex. The gab- broic rocks are present both in the western and eastern sides of the chromian-spinel-bearing ultramafic suite, but are more extensive in the eastern side (Fig. 1). The gabbroic rocks of suite 2 distinctly intrude the chromianspinel-bearing ultramafic rocks along the eastern side of the complex (Figs.1,2). Along the northwestern margin, fragments of the IOG (quartzite) of various sizes are included within the gabbroic mass. Dykes and sills of diabase and clinopyroxenite of suite 3 transgress the earlier two suites along lithological contacts and fractures. Pegmatitic gabbro and quartz diorite intrude the breccia zone in the eastern part of the ultramafic sequence.

The Nuasahi complex has been affected by later faulting, shearing and open folding. ENE-trending faults and shear zones are more prevalent than NNW-trending 
faults. The ultramafic rocks are extensively altered to serpentinite, talc - serpentine schist and talc - serpentine - chlorite schist. Carbonate (mostly aggregates and veins of magnesite) is commonly present in these altered rocks. A hydrated carbonate of chromium, stichtite, is present in highly altered portions of the ultramafic suite (Mondal \& Baidya 1996). The gabbroic rocks now have greenschist-facies assemblages.

\section{Chromian Spinel Mineralization}

Chromian spinel occurs in all of the rocks in the ultramafic suite either as (a) cumulate layers, (b) accessory chromian spinel in enstatitite, olivine orthopyroxenite, dunite, serpentinite and orthopyroxenite units (both as cumulus and intercumulus phases), or (c) disseminated chromian spinel in the sulfide-mineralized zone. Four major magnesiochromite-bearing horizons are present in Suite 1, in stratiform layers interbanded with dunite and orthopyroxenite (Fig. 1). The Durga, Laxmi (Laxmi 2 and Laxmi 1) and Shankar lodes (from west to east in Suite 1) are currently being mined for chromium ore by the Ferro-Alloy Corp. Ltd. (FACOR), Indian Metal \& Ferro-Alloy Corp. Ltd. (IMFA) and the Orissa Mining Corp. (OMC). To the personnel of FACOR Ltd., the faulted counterpart of the Shankar lode at the eastern hill is the Ganga lode. The dunite unit, which is nearly $130-150 \mathrm{~m}$ thick, hosts the first three lodes. At the footwall part of the Durga lode, the exposed dunite unit is $5-10 \mathrm{~m}$ thick and more or less unaltered. The dunite unit in between the Durga and Laxmi 2 lodes is nearly $80 \mathrm{~m}$ thick and has been affected by later faulting and shearing, with different degrees of alteration to serpentinite. The Laxmi 2 and Laxmi 1 chromite lodes are separated by a highly serpentinized dunite unit $\sim 5-6 \mathrm{~m}$ thick. In the hangingwall portion of the Laxmi 1 lode, the dunite unit is $\sim 40$ $60 \mathrm{~m}$ thick and extensively serpentinized. It is in sharp contact with the hanging-wall orthopyroxenite unit, $\sim 80-120 \mathrm{~m}$ thick. The orthopyroxenite unit is highly brecciated in its hanging-wall portion, and is part of the prominent NNW-trending breccia zone (discussed below). The contacts between the chromite lodes and their host dunite units are commonly gradational. The westernmost chromite lode is $\sim 3-4 \mathrm{~m}$ thick; the Laxmi 2 is $2-3 \mathrm{~m}$ thick, and Laxmi 1 is $1.6-1.7 \mathrm{~m}$ thick. The Shankar lode is highly disrupted and occurs in the breccia zone on the eastern margin of the Suite 1 rocks. In the footwall of Laxmi 1 and Laxmi 2 lodes, there is a zone of disseminated chromian spinel ore 2-4 m wide running parallel to the main lodes. Each ore-bearing lode commonly contains, from base to top, (a) schlieren bands, (b) clot-textured bands, (c) massive bands and (d) spotted chromitite bands. Both schlieren and spotted layers grade to massive chromitite bands and show rhythmic banding. In the clot-textured chromitite band, the clots consist of fine-grained chromite that is embedded in a serpentinized matrix. In the more serpentinized part, ferrian chromite occurs as a rim around chromian spinel, and itself is locally rimmed by magnetite. Trails of dusty minute grains of magnetite - ferrian chromite are commonly present in serpentinized parts of the ultramafic unit.

\section{Breccia Zone: Petrography and Mineralogy}

In the eastern part of the ultramafic belt, on the hanging-wall side of the orthopyroxenite unit, a prominent NNW-SSE-trending breccia zone ( 10-15 m thick) is developed (Fig. 1). This zone contains heterogeneous assemblages of differently oriented angular to subrounded fragments of massive, spotted and banded chromitite of Shankar lode and its host ultramafic rocks (mainly serpentinite) (Fig. 2). The matrix of the breccia zone is a complex assemblage of chromite, magnetite ferrian chromite, orthopyroxene, amphibole, biotite, white mica, plagioclase, talc, serpentine-group minerals, clinochlore, carbonate and sulfides. The proportion of these minerals varies along and across the strike of the breccia zone. Asbestos veins are commonly present at the interface or contact part of the adjacent fragments. Pegmatitic gabbro and quartz diorite infill fractures in the breccia zone. The shape and size of the fragments vary from footwall to hanging-wall in the breccia zone. In the footwall, the fragments are rounded to elliptical and smaller, whereas in hanging-wall, they are more angular and larger. The fragments are generally 5-15 m long and 3-5 $\mathrm{m}$ wide near the hanging-wall, 2-3 $\mathrm{m}$ long and $0.5-1.5 \mathrm{~m}$ wide in the middle of the breccia zone, and $5-10 \mathrm{~cm}$ long and $2-4 \mathrm{~cm}$ wide near the footwall. A prominent magnetite + ferrian chromite rim $(\sim 10 \mathrm{~cm}$ wide) is commonly developed around the fragments.

Sulfide mineralization occurs in the matrix of the breccia zone, and in the margins of chromitite fragments, where the sulfide content gradually decreases toward the gabbroic matrix. Locally, sulfides occur as vein, stringer and irregular pockets in the matrix part of the breccia zone. The gabbroic rocks in the hangingwall portion of the breccia zone contain disseminated sulfides in the interstitial space among silicates. Ferrian chromite grains are also distributed in this gabbroic rock, the concentration of which is higher near the contact with the chromitite fragments. A zone of the eastern gabbro hill and another in the northern part of the chromiferous ultramafic belt contain disseminated sulfides in the interstices of silicates. Chalcopyrite, pyrrhotite and pyrite are the common sulfide minerals in the matrix of the breccia zone and also in the gabbroic rock of the hanging-wall portion of breccia zone. Pentlandite, millerite and pyrite occur as major phases in the veins, stringers and pockets, along with chalcopyrite and pyrrhotite. The highest concentration of sulfides is commonly found in the chromite-sulfide assemblage in the breccia zone (up to $50 \%$ ). In general, the occurrence of sulfides is highly variable along and across the strike of the breccia zone, and the concentration is very minor in 
the southern part of the belt. The concentration of sulfide minerals is also highly variable with depth in the breccia zone.

In the chromite-sulfide assemblage of the breccia zone, two size-populations of chromite grains are recognized: coarse grained $(>800 \mu \mathrm{m})$ and fine grained (<600 $\mu \mathrm{m})$ (Fig. 3). The content of coarse-grained chromite is much greater than the finer-grained chromite in this assemblage. Finer-grained crystals of chromite are typically subhedral and subrounded, and show higher reflectivity than the coarser-grained chromite (Figs. 3b, c). An altered rim of clinochlore with considerable content of $\mathrm{Cr}$ (4.71-6.04 wt $\% \mathrm{Cr}_{2} \mathrm{O}_{3}$ ) occurs around the chromite grains (Figs. 3a, b, c, 4a, b, c). Clinochlore is also present in the matrix of this assemblage as concentrated pockets. Chalcopyrite, pyrrhotite (both high-reflectance and low-reflectance varieties) and pyrite are most abundant sulfide minerals in the matrix of this assemblage, with lesser amounts of pentlandite, millerite and bornite. The two varieties of pyrrhotite are optically distinguished in this assemblage. The high-reflectance variety is replaced by chalcopyrite along the cleavages; it occurs as idiomorphic to subidiomorphic grains in a groundmass of chalcopyrite and low-reflectance pyrrhotite. The boundaries between the high-reflectance variety and chalcopyrite were unstable, and now are occupied by younger silicates or iron hydroxides. The low-reflectance pyrrhotite pervades high-reflectance pyrrhotite along the cleavages and occasionally fills fractures in chalcopyrite.

Euhedral crystals of cobaltite-gersdorffite (cb-gd) (Fig. 5) are found in the chalcopyrite-rich matrix of this chromite-sulfide assemblage. These crystals are poikilitically included within the chalcopyrite. Chalcopyrite occasionally infills the fractures within cobaltite-gersdorffite; in places, tongues of chalcopyrite from the surrounding matrix have encroached within the cobaltite-gersdorffite euhedra. Cobaltite-gersdorffite crystals are commonly white, but in some cases shows yellow or light pinkish patches, which may be due to compositional variation. Very minute grains of highreflectance whitish phases (with a yellow tinge) are included in the cobaltite-gersdorffite euhedra. Analytical data for seven cobaltite-gersdorffite grains are listed in Table 1. Composition no. 1 is of a gersdorffite grain with $4.88 \mathrm{wt} \%$ Co and it includes a white phase with yellowish tint (anal. 2). The white phase has a Ni:Co ratio of nearly 1 and is an intermediate member of cobaltitegersdorffite series. The rest of the compositions of cobaltite-gersdorffite of Table 1 show contents of Co that are higher than $\mathrm{Ni}$. The ratio of $\mathrm{Ni}$ :Co ranges from 0.35 to 0.6. The As content is higher than $\mathrm{S}$ in these analyzed grains. The Fe content ranges between 1.76 and 10.63 wt $\%$ and in two grains, the content is higher than that of $\mathrm{Ni}$. The iron-rich cobaltite reported by Cabri \& Laflamme (1976) from the Sudbury ore has Fe contents up to $8.9 \mathrm{wt} \%$. The $\mathrm{Cu}$ content in cobaltite-gersdorffite grains from the Nuasahi suite ranges between 0.99 and
$2.19 \mathrm{wt} \%$, with one grain containing nearly $8.18 \mathrm{wt} \%$. A single grain of cobaltite-gersdorffite from this assemblage (anal. 6, 7) shows compositional variation from core to rim; the core is Fe-enriched, but the content of both $\mathrm{Co}$ and $\mathrm{Ni}$ is higher in the rim. One Cd-bearing mineral was found in the SEM study. It is a very minute grain and attached to a coarser grain of chromite in the chromite-sulfide assemblage. The semiquantitative analysis by EDS reveals its chemical composition to be (in wt\%) Cd 82.91, Pb 8.02, Se 2.10, Fe 1.24, Cu 0.56, Zn 0.71 , oxygen 4.47 .

\section{Platinum-group minerals (PGM)}

Species of platinum-group minerals have been reported from the chromite-sulfide assemblage of the breccia zone (Mondal \& Baidya 1997). Sudburyite is the most common, and preferentially occurs within coarse grains of chromite (Figs. 3e, f). Michenerite (Fig. 4c) occurs with palladian melonite and an Ag-, Bi-, Tebearing phase in the matrix sulfides. Irarsitehollingworthite solid solution forms inclusions in cobaltite-gersdorffite grains occurring within chalcopyrite. Elongate, high-reflectance PGM, the compositions of which have yet to be established, are recognized in sulfide veins within fractured chromite grains. Augé $e t$ al. (1999) reported eighteen PGM species from the breccia zone and also from alluvial concentrates, of which 10 are known species and 8 are unidentified minerals or uncommon end-members of known species. The PGM grains are characterized by small grain-size, on average 5-10 $\mu \mathrm{m}$, but larger grains, $200 \times 150 \mu \mathrm{m}$, have been identified in alluvial concentrates (Augé et al. 1999).

TABLE 1. COMPOSITION OF COBALTITE-GERSDORFFITE, BRECCIA ZONE OF THE NUASAHI COMPLEX, ORISSA, INDIA

\begin{tabular}{|c|c|c|c|c|c|c|c|c|}
\hline & $\begin{array}{c}\mathrm{CS} 1 \\
\mathrm{C} / 5-3\end{array}$ & $\underset{C / 5-5}{C S 1}$ & $\begin{array}{l}\mathrm{FCS} / 1 \\
\mathrm{C} / 2-6\end{array}$ & $\begin{array}{l}\mathrm{FCS} / 1 \\
\mathrm{C} / 3-7\end{array}$ & $\begin{array}{l}\mathrm{FCS} / 1 \\
\mathrm{C} / 4-8\end{array}$ & $\begin{array}{c}\mathrm{FCS} / 1 \\
\mathrm{C} / 3-1 \mathrm{a} \\
\text { core }\end{array}$ & $\begin{array}{c}\mathrm{FCS} / 1 \\
\mathrm{C} / 3-1 \mathrm{~b} \\
\mathrm{rim}\end{array}$ & $\begin{array}{r}\mathrm{FCS} / 9 \\
\mathrm{C} 4-9\end{array}$ \\
\hline Co wt $\%$ & 4.88 & 17.08 & 20.99 & 23.02 & 23.35 & 24.02 & 26.20 & 20.46 \\
\hline $\mathrm{Ni}$ & 30.70 & 17.47 & 12.62 & 9.89 & 9.63 & 8.53 & 15.48 & 12.03 \\
\hline As & 40.22 & 39.77 & 41.88 & 42.17 & 41.95 & 38.66 & 31.25 & 25.52 \\
\hline $\mathbf{S}$ & 22.40 & 22.74 & 20.51 & 20.75 & 20.60 & 16.33 & 20.42 & 22.39 \\
\hline $\mathrm{Fe}$ & 1.76 & 1.99 & 3.78 & 3.88 & 4.27 & 10.63 & 4.46 & 10.44 \\
\hline $\mathrm{Cu}$ & 1.20 & 0.99 & 1.28 & 1.62 & 1.96 & 1.79 & 2.19 & 8.18 \\
\hline Ir & & & & & & & & 0.99 \\
\hline total & 101.17 & 100.04 & 101.06 & 101.32 & 101.75 & 100.00 & 100.00 & 100.00 \\
\hline Co at. $\%$ & 4.38 & 15.43 & 19.17 & 20.95 & 21.18 & 22.72 & 23.69 & 18.16 \\
\hline $\mathrm{Ni}$ & 27.64 & 15.84 & 11.57 & 9.03 & 8.77 & 8.08 & 14.05 & 10.71 \\
\hline As & 28.38 & 28.25 & 30.09 & 30.20 & 29.94 & 28.71 & 22.23 & 17.82 \\
\hline $\mathrm{S}$ & 36.94 & 37.75 & 34.42 & 34.72 & 34.36 & 28.33 & 33.93 & 36.53 \\
\hline $\mathrm{Fe}$ & 1.66 & 1.89 & 3.64 & 3.73 & 4.09 & 10.59 & 4.26 & 9.77 \\
\hline $\mathrm{Cu}$ & 1.01 & 0.83 & 1.09 & 1.37 & 1.65 & 1.57 & 1.83 & 6.73 \\
\hline Ir & & & & & & & & 0.27 \\
\hline
\end{tabular}

Columns 2-6; the analyses were done with a JEOL-IXA $8600 \mathrm{M}$ Superprobe. Columns 7-9; the analyses were done with a Leo-Leica Stereoscan 440 scanning electron microscope equipped with energy-dispersion spectroscopy. 


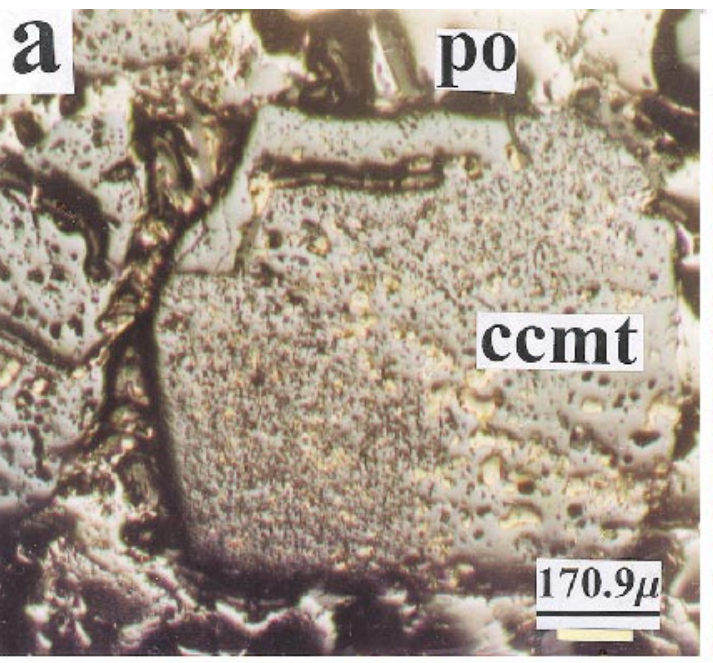

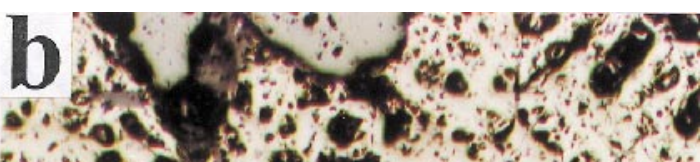

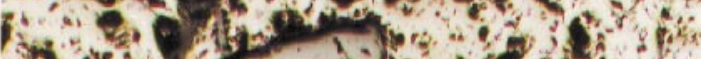

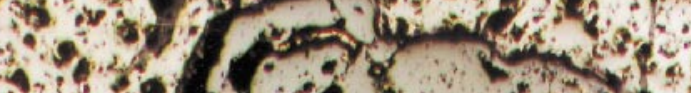

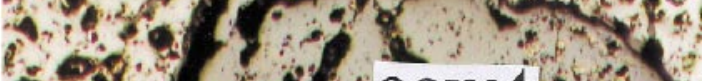

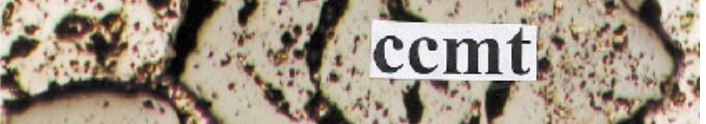

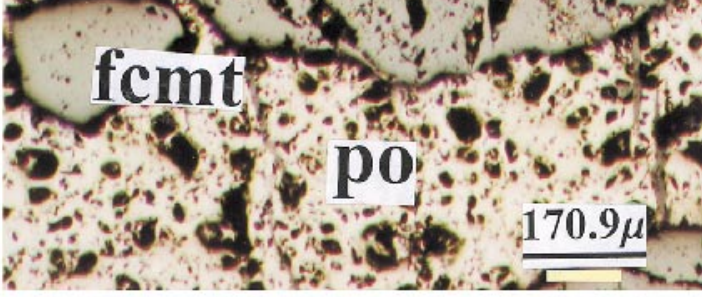
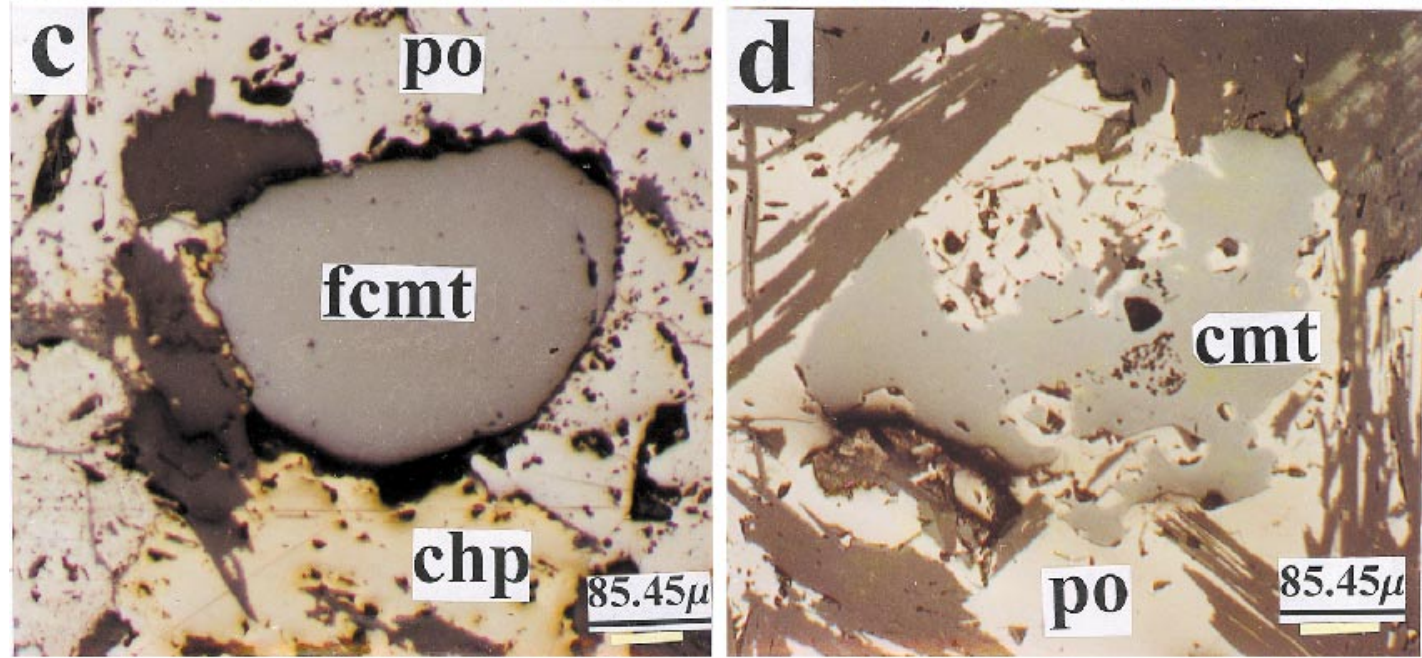

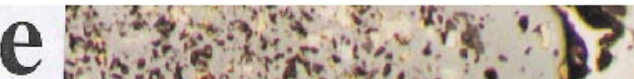

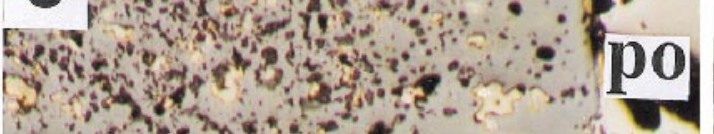

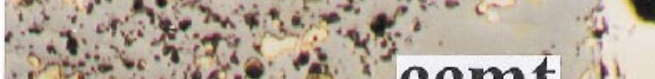
2rone cent

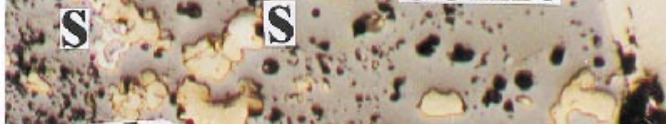
*Chp

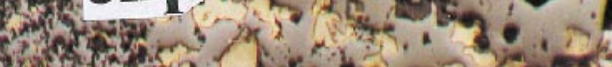

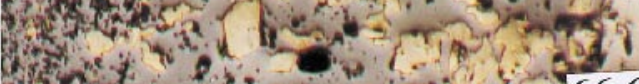

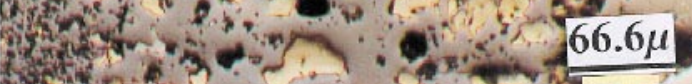

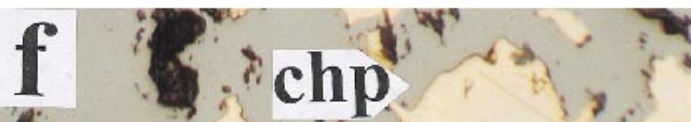

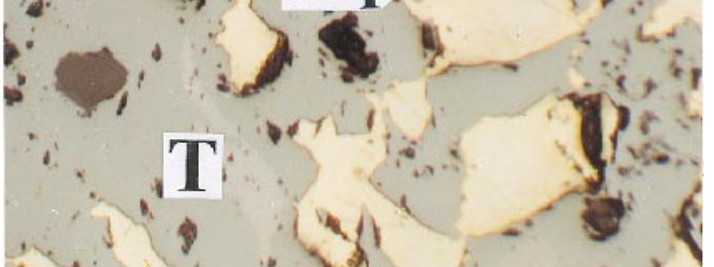
is $x,-6$ 

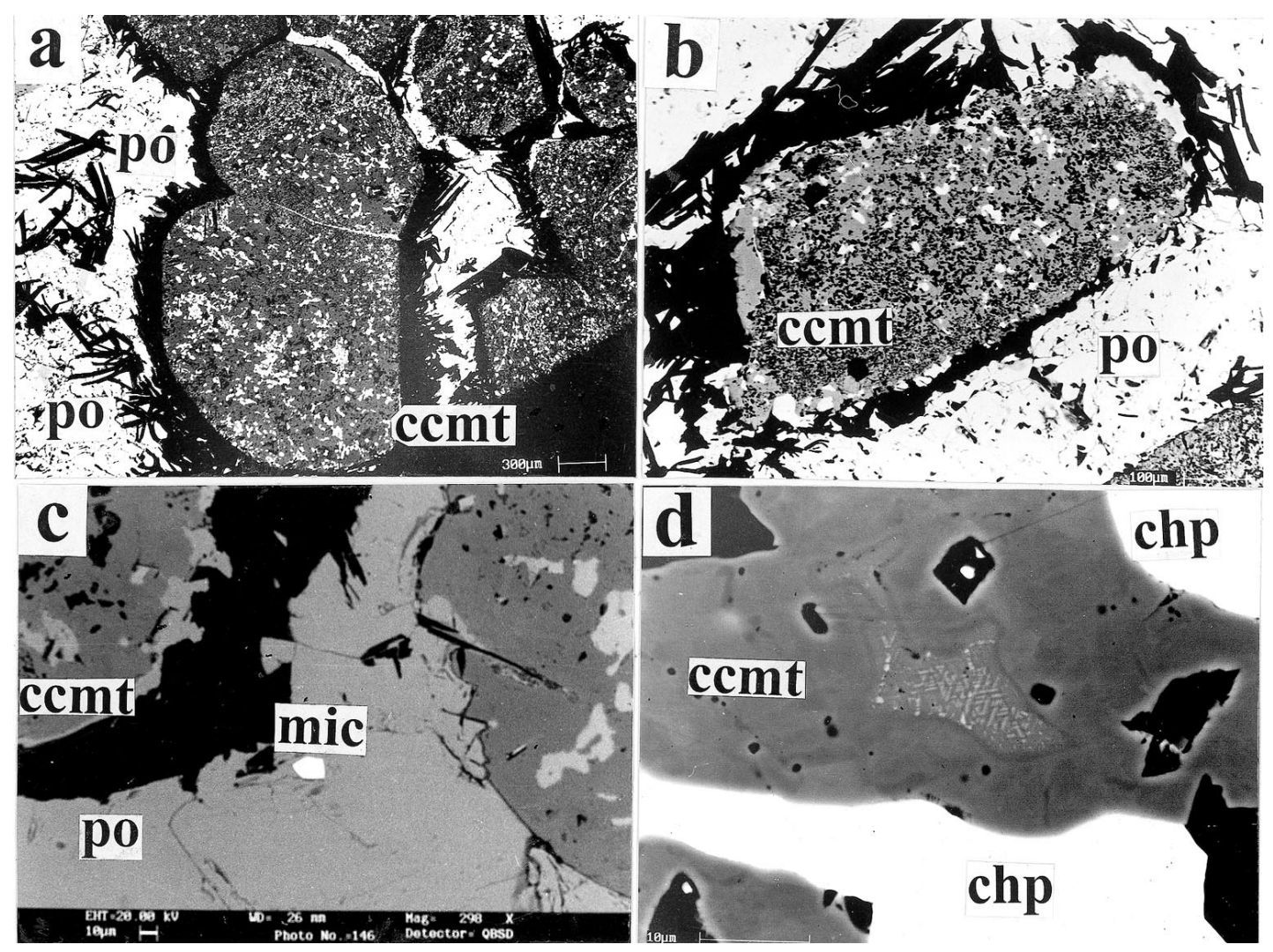

FIG. 4. SEM photomicrographs of chromite-sulfide assemblage, Breccia Zone. (a) Inclusions in coarser-grained chromite (ccmt). Matrix material consists of pyrrhotite (po), chalcopyrite (chp) and clinochlore (black). (b) Inclusions in coarser-grained chromite (ccmt). Chromite is replaced by sulfides along the boundary. Matrix material consists of pyrrhotite (po), chalcopyrite (chp) and clinochlore (black). (c) Euhedral crystal of michenerite (mic) in pyrrhotite (po). Chromite crystals (ccmt) are replaced by sulfides and silicates along the boundaries. (d) Coarser-grained chromite shows inclusions of chalcopyrite (chp), clinochlore (black) and Ti-bearing oxide phase. Exsolved lamellae in included oxide phase are visible at the middle part of the photomicrograph.

FIG. 3. Photomicrographs of chromite-sulfide assemblage, Breccia Zone. (a) Coarser-grained chromite (ccmt) with numerous inclusions (po pyrrhotite). (b) Coarser-grained chromite (ccmt) showing "fused" texture with inclusions. One finer-grained chromite (fcmt) is present to the left of the coarser-grained chromite. Matrix material consists of pyrrhotite (po). (c) Finer-grained chromite (fcmt) in sulfide-rich matrix containing chalopyrite (chp) and pyrrhotite (po). Black material is clinochlore. (d) Chromite (cmt) extensively replaced by sulfides (po) in the chromitesulfide assemblage. (e) Coarser-grained chromite (ccmt) with numerous inclusions of chalcopyrite with sudburyite (s). Matrix material consists of pyrrhotite. (f) Coarsergrained chromite (ccmt) shows inclusions of chalcopyrite, sudburyite and Ti-bearing oxide phases $(\mathrm{T})$.

\section{Inclusions in chromite}

Ferrian chromite crystals in gabbroic rock in the hanging-wall of breccia zone, from the matrix of the breccia zone, and also the coarser-grained chromite in chromite-sulfide assemblage contain numerous inclusions of silicates, base-metal sulfides $(B M S)$ and oxide phases (Figs. 3, 4). The finer-grained chromite crystals of the chromite-sulfide assemblage contain tiny inclusions of rutile and, rarely, sulfides. Locally, subrounded inclusions of silicate assemblages containing biotite, plagioclase, ferroan tremolite and sulfides are present in the chromite crystals of gabbroic rock from the hanging-wall of the breccia zone. Three sets of oriented chlorite lamellae and tiny inclusions of rutile also are present within some chromite grains of this assemblage and also from the matrix portion of the breccia zone. Tiny grains of rutile are absent in magnesiochromite from the inte- 

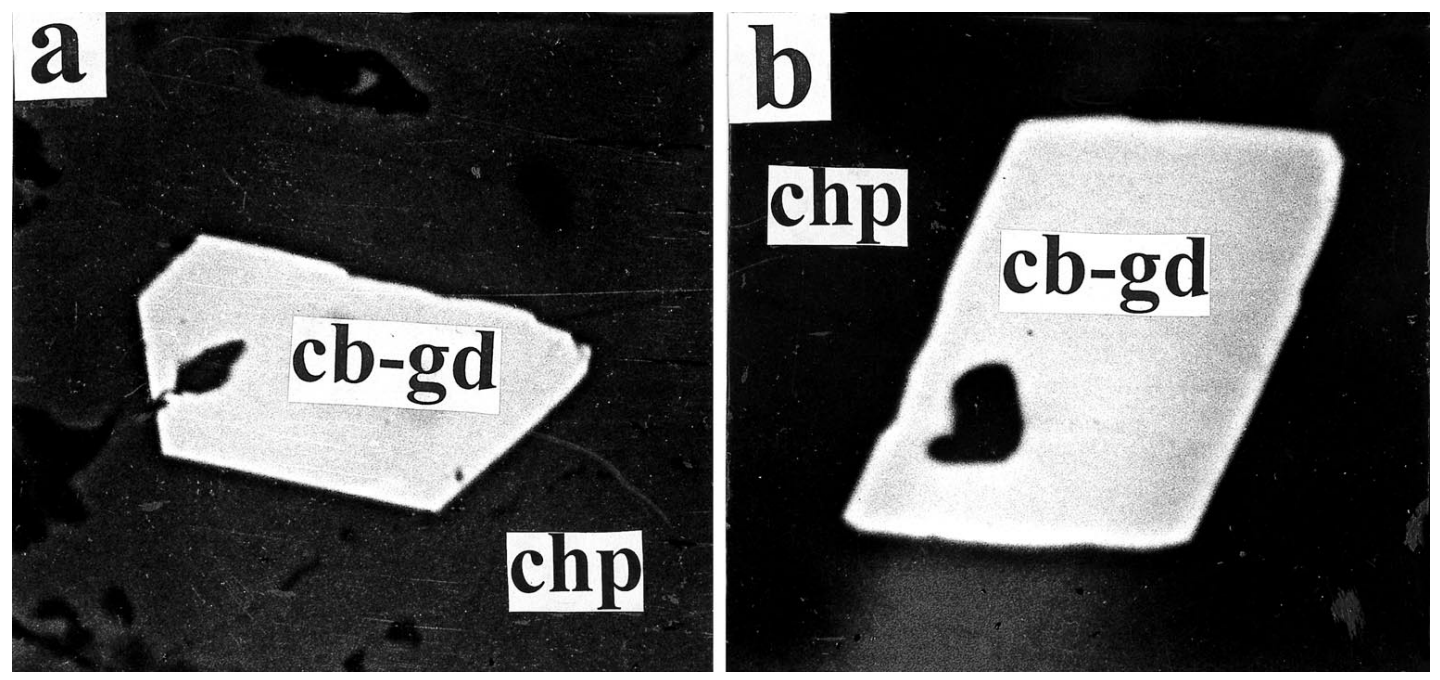

FIG. 5. SEM photomicrographs showing cobaltite-gersdorffite (cb-gd) euhedra in chalcopyrite-rich matrix in the chromitesulfide assemblage of the breccia zone. Width of crystals: $30 \mu \mathrm{m}$ in a, $20 \mu \mathrm{m}$ in b.

rior part of the chromitite fragments, but abundant in the chromite crystals from the boundary portion of the fragments. The coarser grains of chromite of the chromite-sulfide assemblage contain profuse inclusions of BMS (chalcopyrite, pyrrhotite and pentlandite), silicates (clinochlore, serpentine), oxides (rutile, ilmenite and $\mathrm{Cr}$-Ti-bearing oxides) and PGM (Figs. 3a, b, e, f, $4 \mathrm{a}, \mathrm{b}, \mathrm{c}, \mathrm{d})$. Chalcopyrite is the principal $B M S$ present as inclusions. Rutile and ilmenite are the common oxide minerals included within coarser-grained chromite. Some included phases contain exsolved lamellae (Fig. 4d), of unknown composition. The included phases are highly irregular in shape (mostly dendritic) and locally display worm-like textures (Fig. 4a). In places, two or more chromite grains became "fused" together (Fig. 3b) and developed a composite chromite grain with variable amounts of inclusions concentrated in different portions of the grain. The size, shape and relative abundance of the inclusion minerals are highly variable, even within a single grain. The included sulfides and silicates, as well as the matrix sulfides and silicates (Fig. $3 \mathrm{~d}, 4 \mathrm{~b}, \mathrm{c})$, extensively replace chromite crystals in this assemblage.

\section{Compositions of Chromian Spinel}

The chromian spinel compositions for few representative samples are listed in Table 2; they are recalculated to cation proportions using the $\mathrm{Fe}^{3+}$ calculation scheme of Droop (1987). The unaltered magnesiochromite of four massive chromitite bands (lode chromite) show minor variation in chemical composi- tion, with $\sim 60$ wt $\% \mathrm{Cr}_{2} \mathrm{O}_{3}$, and $\mathrm{Mg \#}$ ranges between 0.71 and 0.80 (anal. 1-8; Fig. 6). The $\mathrm{FeO}$ and $\mathrm{Fe}_{2} \mathrm{O}_{3}$ content are significantly higher for the chromian spinel in the sulfide-rich assemblages in the breccia zone, with concomitant low contents of $\mathrm{MgO}$ and $\mathrm{Cr}_{2} \mathrm{O}_{3}$, with $\mathrm{Mg \#}$ in the range between 0.01 and 0.17 (anal. 9-15; Fig. 6). The $\mathrm{Al}_{2} \mathrm{O}_{3}$ content remains fairly constant in chromian spinel from all assemblages with the exception of a few grains in the gabbroic rock from the hanging-wall of the breccia zone (anal. 9, 10; Fig. 6). The finer-grained chromite of the chromite-sulfide assemblage (anal. 14, 15 ) of the breccia zone has a similar composition to that of chromite from gabbroic rock (anal. 9, 10) in the hanging-wall of breccia zone. The presence of rutile and $\mathrm{Cr}$-Ti-bearing mineral inclusions in chromite from the mineralized breccia zone has been confirmed by electron-mircoprobe analyses (anal. 16-20).

\section{Geochemistry of the Breccia Zone AND \\ Distribution of PGE and Other Trace Elements}

\section{Whole-rock geochemistry}

Table 3 shows the whole-rock analytical data for six rock samples. Samples B/S/11 and B/S/16 are sulfidebearing assemblages from the matrix of the breccia zone. The sample of serpentinite $(\mathrm{OC} / \mathrm{S} / 2)$, an alteration product of dunite, contains considerable carbonate. The samples of breccia zone (B/S/9, B/S/11, B/S/16) have high $\mathrm{Al}, \mathrm{K}, \mathrm{Ti}, \mathrm{Ca}$ and $\mathrm{Na}$, and extremely variable $\mathrm{Fe}$ and $\mathrm{Cr}$ contents (presumably a function of physically included chromite). Some of these fragments must be 
TABLE 2. COMPOSITION OF CHROMIAN SPINEL FROM THE NUASAHI ULTRAMAFIC-MAFIC COMPLEX, ORISSA, INDIA

\begin{tabular}{|c|c|c|c|c|c|c|c|c|c|c|c|c|c|c|c|c|c|c|c|c|}
\hline Sample & $\mathrm{o} / 1$ & $\mathrm{O} / 1$ & $\mathrm{O} / 2$ & $\mathrm{O} / 2$ & $\mathrm{O} / 3$ & $\mathrm{O} / 3$ & $\begin{array}{l}\mathrm{B} / \mathrm{S} \\
/ 15\end{array}$ & $\begin{array}{l}\mathrm{B} / \mathrm{S} \\
/ 15\end{array}$ & $\begin{array}{l}\mathrm{B} / \mathrm{S} \\
/ 16\end{array}$ & $\begin{array}{l}\mathrm{B} / \mathrm{S} \\
/ 16\end{array}$ & $\begin{array}{c}\mathrm{NF} / 12 \\
\text { /SNK } \\
/ \mathrm{C}\end{array}$ & $\begin{array}{c}\mathrm{NF} / 12 \\
/ \mathrm{SNK} \\
/ \mathrm{C}\end{array}$ & $\begin{array}{c}\mathrm{NF} / 12 \\
/ \mathrm{SNK} \\
/ \mathrm{C}\end{array}$ & $\begin{array}{c}\text { FCS } \\
/ 7\end{array}$ & $\begin{array}{c}\text { FCS } \\
17\end{array}$ & $\begin{array}{c}\mathrm{NF} / 12 \\
/ \mathrm{SNK} \\
/ \mathrm{C}\end{array}$ & $\begin{array}{c}\mathrm{NF} / 12 \\
/ \mathrm{SNK} \\
/ \mathrm{C}\end{array}$ & $\begin{array}{c}\mathrm{NF} / 12 \\
/ \mathrm{SNK} \\
/ \mathrm{C}\end{array}$ & $\begin{array}{l}\mathrm{NF} / 12 \\
/ \mathrm{SNK} \\
/ \mathrm{C}\end{array}$ & $\begin{array}{c}\mathrm{NF} / 12 \\
/ \mathrm{SNK} \\
/ \mathrm{C}\end{array}$ \\
\hline & 1 & 2 & 3 & 4 & 5 & 6 & 7 & 8 & 9 & 10 & 11 & 12 & 13 & 14 & 15 & 16 & 17 & 18 & 19 & 20 \\
\hline
\end{tabular}

\begin{tabular}{|c|c|c|c|c|c|c|c|c|c|c|c|c|c|c|c|c|c|c|c|c|}
\hline $\mathrm{SiO}_{2} \mathrm{wt} \%$ & - & - & - & - & - & - & - & - & - & - & - & - & - & - & - & - & - & - & 0.06 & - \\
\hline $\mathrm{TiO}_{2}$ & 0.13 & 0.15 & 0.17 & 0.17 & 0.20 & 0.17 & 0.19 & 0.21 & 1.95 & 1.37 & 0.47 & 4.18 & 0.07 & 1.51 & $2.04 s$ & 95.509 & 97.72 & 87.87 & 55.89 & 61.97 \\
\hline $\mathrm{Al}_{2} \mathrm{O}_{3}$ & 9.82 & 10.29 & 10.841 & 11.13 & 10.621 & 11.14 & 10.87 & 10.84 & 6.28 & 6.02 & 11.191 & 11.251 & 13.20 & 9.21 & 9.66 & 0.01 & - & 1.10 & 4.36 & 2.78 \\
\hline $\mathrm{Cr}_{2} \mathrm{O}_{3}$ & 62.10 & 63.296 & 60.126 & 60.19 & 60.086 & 60.30 & 59.16 & 60.14 & 33.97 & 35.50 & 43.194 & 41.054 & 45.043 & 31.963 & 30.51 & 0.51 & 0.67 & 5.892 & 20.93 & 16.46 \\
\hline $\mathrm{Fe}_{2} \mathrm{O}_{3}$ & 3.12 & 2.79 & 3.46 & 3.86 & 4.01 & 3.32 & 3.92 & 4.052 & 27.61 & 25.56 & 12.70 & 7.88 & 6.232 & 26.182 & 21.25 & - & - & - & - & - \\
\hline $\mathrm{FeO}$ & 7.56 & 9.04 & 9.59 & 9.29 & 9.47 & 9.641 & 10.71 & 10.63 & 28.51 & 29.88 & 28.723 & 31.002 & 29.402 & 27.783 & 30.33 & 2.91 & 1.48 & 4.35 & 15.16 & 11.90 \\
\hline $\mathrm{MnO}$ & 0.39 & 0.17 & 0.33 & 0.27 & 0.20 & 0.19 & 0.29 & 0.44 & 0.85 & 0.99 & 0.33 & 0.21 & 0.35 & 0.27 & 0.33 & - & 0.02 & 0.05 & 0.11 & 0.11 \\
\hline $\mathrm{MgO}$ & 16,75 & 16.44 & 15.661 & 16.09 & 15.781 & 15.87 & 14.85 & 15.22 & 0.25 & 0.13 & 3.23 & 3.53 & 2.08 & 2.52 & 2.07 & 0.24 & 0.02 & 0.12 & 0.82 & 0.64 \\
\hline $\mathrm{CaO}$ & 0.01 & - & 0.02 & 0.01 & 0.03 & 0.03 & 0.05 & 0.01 & - & - & - & - & 0.01 & - & - & 0.05 & 0.04 & 0.33 & 0.65 & 2.91 \\
\hline $\mathrm{Na}_{2} \mathrm{O}$ & & & & & & & & & 1.13 & 0.63 & - & 0.12 & - & 0.58 & - & - & - & 0.22 & - & - \\
\hline $\mathrm{K}_{2} \mathrm{O}$ & & & & & & & & & - & - & - & - & - & - & - & - & - & - & " & - \\
\hline $\mathrm{ZnO}$ & 0.10 & 0.24 & 0.04 & 0.24 & 0.06 & 0.04 & - & - & - & 0.08 & 0.04 & 0.09 & & & & & & & & \\
\hline $\mathrm{V}_{2} \mathrm{O}_{3}$ & 0.01 & 0.01 & 0.01 & 0.01 & 0.01 & 0.01 & 0.01 & 0.01 & 0.03 & 0.03 & 0.03 & 0.04 & 0.03 & 0.03 & 0.03 & 0.37 & 0.42 & 0.48 & 0.32 & 0.36 \\
\hline $\mathrm{BaO}$ & & & & & & & & & 0.01 & 0.02 & 0.06 & - & - & 0.03 & 0.04 & 0.54 & 0.60 & 0.39 & 0.30 & 0.24 \\
\hline $\mathrm{NiO}$ & 0.09 & 0.19 & 0.05 & 0.08 & 0.22 & - & 0.22 & 0.11 & - & 0.03 & 0.02 & - & - & 0.11 & 0.09 & - & 0.10 & 0.01 & 0.05 & - \\
\hline Total & 99.981 & 102.3710 & 100.281 & $101.09 \mathrm{l}$ & 100.6210 & $100.67 \mathrm{I}$ & 100.271 & $101.65 \mathrm{l}$ & 100.691 & 100.40 & 99.98 & 99.509 & 96.471 & 100.22 & 96.351 & 100.1310 & 101.071 & 100.89 & 98.69 & 97.46 \\
\hline Si apfu & - & - & - & - & - & - & - & - & - & - & - & - & - & - & - & - & - & - & 0.002 & $2-$ \\
\hline Al & 0.366 & $\begin{array}{ll}5 & 0.376\end{array}$ & 0.404 & +0.411 & 0.395 & 0.413 & 0.408 & 3 0.401 & 0.265 & $\begin{array}{ll}5 & 0.257\end{array}$ & 0.457 & 0.459 & 0.556 & 0.381 & 0.417 & 70.001 & - & 0.035 & 0.156 & $\begin{array}{l}5 \\
0.099\end{array}$ \\
\hline $\mathrm{Ti}$ & 0.003 & 30.003 & 0.004 & +0.004 & 0.005 & 0.004 & 0.005 & 50.005 & 50.052 & 20.037 & 0.012 & 20.109 & 0.002 & 0.039 & 0.056 & 51.944 & 1.961 & 1.806 & 1.274 & 41.409 \\
\hline $\mathrm{Fe}^{3+}$ & 0.074 & 40.065 & 0.082 & 0.091 & 0.095 & 0.079 & 0.094 & 40.096 & $\begin{array}{ll}6 & 0.744\end{array}$ & 40.696 & 0.332 & 0.206 & 0.167 & 0.691 & 0.586 & $6-$ & - & - & - & - \\
\hline $\mathrm{Fe}^{2+}$ & 0.199 & 0.234 & 3.456 & 0.243 & 0.250 & 0.254 & 0.285 & $\begin{array}{ll}5 & 0.279\end{array}$ & 0.854 & 40.905 & 0.833 & 30.898 & 0.878 & 0.815 & 0.929 & 0.066 & 0.033 & 0.099 & 0.384 & $\begin{array}{ll}4 & 0.301\end{array}$ \\
\hline $\mathrm{Cr}$ & 1.553 & 31.552 & 1.505 & 1.490 & 1.500 & 1.500 & 1.489 & 1.492 & 20.962 & 21.016 & 1.185 & 51.124 & 1.272 & 0.887 & 0.884 & 40.011 & 0.014 & 0.127 & 0.501 & 0.393 \\
\hline $\mathrm{Zn}$ & & & & & & & & & 0.003 & 30.006 & 0.001 & 10.006 & 0.001 & 0.001 & - & - & - & 0.002 & 0.001 & 10.002 \\
\hline Mn & 0.010 & 0.004 & 0.009 & 0.007 & 0.005 & 0.005 & 0.008 & 8 0.012 & 20.026 & 60.030 & 0.009 & 0.006 & 0.011 & 0.008 & 0.010 & 0 & 0.001 & 0.001 & 0.003 & 0.003 \\
\hline $\mathrm{Mg}$ & 0.790 & 0.760 & 0.739 & 0.751 & 0.743 & 0.744 & 0.705 & 50.712 & 20.013 & 30.007 & 0.167 & 70.182 & 0.111 & 0.132 & 0.113 & 30.009 & 0.001 & 0.005 & 0.037 & $\begin{array}{l}70.029 \\
\end{array}$ \\
\hline $\mathrm{Ca}$ & 0.001 & $1-$ & 0.001 & 0.001 & 0.001 & 0.001 & 0.002 & 20.001 & $1-$ & - & - & - & 0.001 & - & - & 0.001 & 0.001 & 0.009 & 0.021 & 0.094 \\
\hline $\mathrm{Na}$ & & & & & & & & & 0.078 & 80.044 & - & 0.008 & - & 0.039 & - & - & - & 0.012 & - & - \\
\hline $\mathbf{K}$ & & & & & & & & & - & - & - & - & - & - & - & - & - & - & - & - \\
\hline $\mathrm{Ba}$ & & & & & & & & & 0.001 & $1 \quad 0.001$ & 0.001 & $1-$ & - & - & 0.001 & 0.006 & 0.006 & 0.004 & 0.003 & 30.003 \\
\hline V & 0.001 & $1-$ & 0.001 & 0.001 & 0.001 & 0.001 & - & 0.001 & 10.001 & 10.002 & 0.001 & 0.001 & 0.001 & 0.001 & 0.001 & 0.007 & 0.008 & 0.010 & 0.007 & $7 \quad 0.009$ \\
\hline $\mathrm{Ni}$ & 0.002 & 20.005 & 0.001 & 0.002 & 0.005 & - & 0.006 & 50.003 & $3-$ & 0.001 & 0.004 & $4-$ & - & 0.003 & 0.003 & $3-$ & 0.002 & 0.001 & 0.001 & $1-$ \\
\hline$\Sigma$ cations & 3.00 & 3.00 & 3.00 & 3.00 & 3.00 & 3.00 & 3.00 & 3.00 & 3.00 & 3.00 & 3.00 & 3.00 & 3.00 & 3.00 & 3.00 & 2.046 & 2.027 & 2.112 & 2.391 & l 2.341 \\
\hline $\mathrm{CH}$ & 0.81 & 0.80 & 0.79 & 0.78 & 0.79 & 0.78 & 0.78 & 0.79 & 0.78 & 0.80 & 0.72 & 0.71 & 0.70 & 0.70 & 0.68 & & & & & \\
\hline Mg\# & 0.80 & 0.76 & 0.74 & 0.76 & 0.75 & 0.75 & 0.71 & 0.72 & 0.02 & 0.01 & 0.17 & 0.17 & 0.11 & 0.14 & 0.11 & & & & & \\
\hline
\end{tabular}

The structural formula, expressed atoms per formula unit, apfu, is based on four atoms of oxygen. Samples: columns 1-8: seam magnesiochromite; $0 / 1$ Durga lode, O/2 Laxmi-2 lode, O/3 Laxmi-1 lode, B/S/15 Shankar lode. Columns 9, 10: chromite from sulfide-rich gabbroic rock (hanging-wall of the breccia zone). Columns 11-15: chromite from chromite-sulfide assemblage of the breccia zone; 11-13: coarser-grained chromite, 14, 15: finer-grained chromite. Columns 16-20: included Ti-bearing oxide phases in coarser chromite. The $\mathrm{FeO}$ value reported is total $\mathrm{FeO}$. $\mathrm{Cr} \# \mathbf{\mathrm { Cr }} /(\mathrm{Cr}+\mathrm{Al})$; $\mathrm{Mg} \#: \mathrm{Mg} /\left(\mathrm{Mg}+\mathrm{Fe}{ }^{2+}\right)$. $\mathrm{Blank} \mathrm{space}$ : not determined. The data are derived from electron-microprobe analyses.

orthopyroxenite, as they have high $\mathrm{Si}$ and $\mathrm{Mg}$ and low $\mathrm{Ca}$ and $\mathrm{Al}$. The one sample of quartz diorite (B/S/9) shows higher concentration of $\mathrm{Cr}, \mathrm{Ni}, \mathrm{V}$ and $\mathrm{Ti}$ (1316, 220, $124 \mathrm{ppm}, 0.54 \mathrm{wt} \% \mathrm{TiO}_{2}$ respectively) than the typical gabbro (S/17; 463, 160, $110 \mathrm{ppm}, 0.31 \mathrm{wt} \% \mathrm{TiO}_{2}$ respectively). The high $\mathrm{Ni}$ and $\mathrm{Co}$ content in the two samples of breccia zone (B/S/11 and B/S16) is due to presence of base-metal sulfide in the assemblage. The $\mathrm{Zn}$ content is also higher $(85,232 \mathrm{ppm}$, respectively) in these two samples. The chondrite-normalized rare-earthelement $(R E E)$ patterns for these samples are shown in Figure 7. All of the samples show extreme enrichment in the light $R E E$ ( $L R E E)$. There are three distinct trends, one for the gabbroic rocks (S/17 and B/S/9), one for the sulfide-bearing matrix samples of the breccia zone (B/ $\mathrm{S} / 11$ and $\mathrm{B} / \mathrm{S} / 16$ ), and one for the ultramafic rocks (OC/ $\mathrm{S} / 2$ and $\mathrm{PX} / 22$ ). There may be a problem with both La and $\mathrm{Sm}$ data; both seem to have unusually low contents with respect to adjacent $L R E E$, but this may be due to the unusual composition of the samples.

\section{Distribution of PGE and other trace elements}

Table 4 shows the noble- and trace-element contents of the various samples. The sulfide-bearing rocks of the breccia zone contain high PGE tenors, with variable 


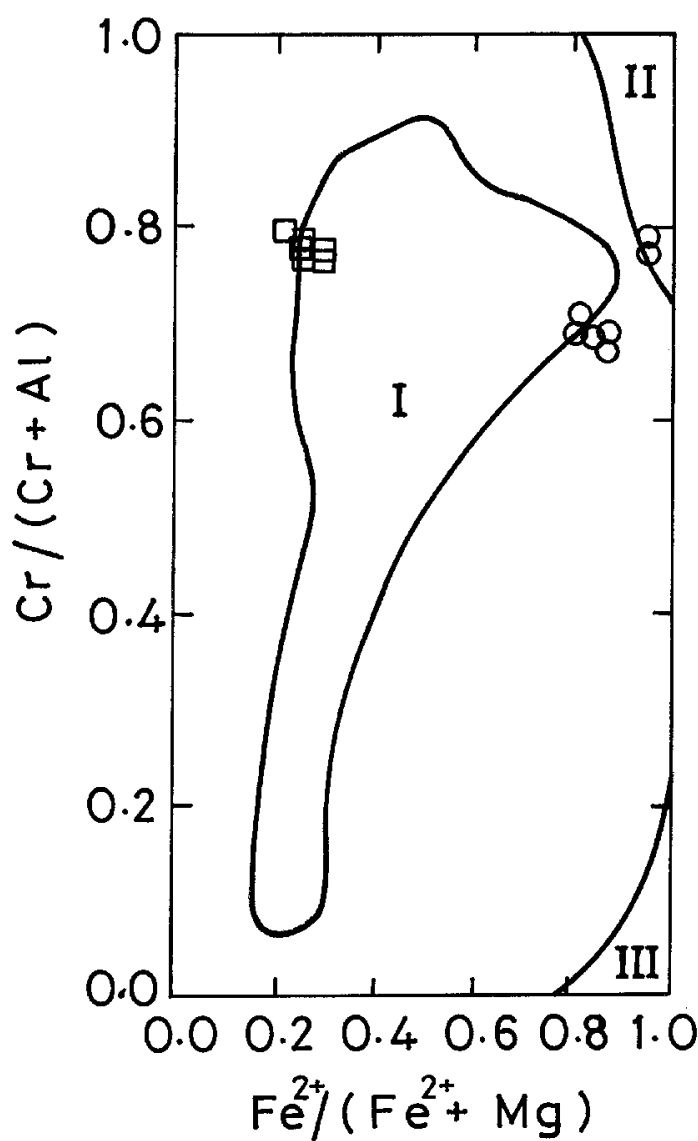

FIG. 6. Plot of compositions of chromian spinel from the Nuasahi Complex in terms of $\mathrm{Cr} /(\mathrm{Cr}+\mathrm{Al})$ versus $\mathrm{Fe}^{2+}$ / $\left(\mathrm{Fe}^{2+}+\mathrm{Mg}\right)$. Open squares: magnesiochromite in massive chromitite bands of four lodes, open circles: ferrian chromite from the sulfide-rich assemblage of the breccia zone. Field I: compositions of chromian spinel associated with magnesian olivine in primitive basaltic rocks, mantle peridotite and chromitite. Field II: compositions of chromian spinel (magnetite) from metamorphic rocks. Field III: compositions of chromian spinel (magnetite) from fresh igneous rocks (after Roeder 1994).

$\mathrm{Pd}: \mathrm{Pt}$ ratios and $\mathrm{Au}$, base metal and $\mathrm{Ag}$ tenors. It is evident that the chromite-sulfide assemblage of the breccia zone (samples NF/12/SNK/C, NS/1, NS/3, NS/4, B/ $\mathrm{O} / 4$, FCS/7; Fig. 8) contains a high tenor of $\mathrm{Pt}$ (up to $9.59 \mathrm{ppm}$ ), Pd (up to $17.9 \mathrm{ppm}$ ) and $\mathrm{Ag}$ (up to 6.63 ppm). The Pd- and Pt-bearing PGM are the common phases found in this assemblage. The base-metal $(\mathrm{Ni}$, $\mathrm{Cu}, \mathrm{Co}$ ) content is also high for this chromite-sulfide assemblage of the breccia zone (Table 4). The samples of the sulfide-rich gabbroic rock from the hanging-wall portion of the breccia zone also contain a high tenor of $\mathrm{Pt}$, Pd and Ag (samples NF/13/SNK, FCS/14, NS/2;

\begin{tabular}{|c|c|c|c|c|c|c|}
\hline & $\mathrm{PX} / 22$ & $\mathrm{OC} / \mathrm{S} / 2$ & $\$ / 17$ & $\mathrm{~B} / \mathrm{S} / 9$ & $\mathrm{~B} / \mathrm{S} / 11$ & $\mathrm{~B} / \mathrm{S} / 16$ \\
\hline $\mathrm{SiO}_{2} \mathrm{wt} \%$ & 54.89 & 44.37 & 52.84 & 61.71 & 54.97 & 52.71 \\
\hline $\mathrm{TiO}_{2}$ & 0.09 & 0.14 & 0.31 & 0.54 & 0.44 & 0.72 \\
\hline $\mathrm{Al}_{2} \mathrm{O}_{3}$ & 0.95 & 1.00 & 17.97 & 17.72 & 4.06 & 6.86 \\
\hline $\mathrm{FeO}$ (total) & 6.09 & 4.98 & 7.42 & 6.33 & 9.07 & 19.52 \\
\hline $\mathrm{MnO}$ & 0.13 & 0.09 & 0.14 & 0.07 & 0.15 & 0.21 \\
\hline $\mathrm{MgO}$ & 27.48 & 32.73 & 6.47 & 4.28 & 20.96 & 13.58 \\
\hline $\mathrm{CaO}$ & 0.69 & 0.31 & 8.89 & 0.48 & 6.23 & 3.39 \\
\hline $\mathrm{Na}_{2} \mathrm{O}$ & 0.03 & 0.03 & 2.86 & 6.01 & 0.08 & 0.95 \\
\hline $\mathrm{K}_{2} \mathrm{O}$ & 0.31 & 0.23 & $<0.39$ & 0.72 & 0.34 & 1.17 \\
\hline $\mathrm{H}_{2}^{2} \mathrm{O}$ & 5.84 & 3.23 & 2.72 & 3.32 & 3.71 & 1.68 \\
\hline $\mathrm{CO}_{2}$ & - & 15.69 & - & - & tr. & - \\
\hline total & 96.48 & 102.79 & 100.00 & 101.18 & 100.00 & 100.78 \\
\hline Sc ppm & 10.98 & 4.92 & 18.93 & 17.18 & 13.89 & 25.00 \\
\hline V & 48.1 & 45.2 & 110.0 & 124.0 & 294.4 & 786.7 \\
\hline $\mathrm{Cr}$ & 7871 & 16706 & 463 & 1316 & 15042 & 50533 \\
\hline Co & 77.13 & 83.15 & 46.99 & 28.90 & 77.11 & 194.68 \\
\hline $\mathrm{Ni}$ & 443 & 1358 & 160 & 220 & 360 & 1834 \\
\hline $\mathrm{Zn}$ & 51.8 & 18.9 & 65.0 & 40.6 & 84.6 & 232 \\
\hline$R b$ & $<5.1$ & $<5.4$ & $<5.2$ & 31.6 & $<6.0$ & 27.6 \\
\hline $\mathrm{Sr}$ & $<70$ & $<64$ & 233 & 204 & $<83$ & 157 \\
\hline $\mathrm{Zr}$ & $<54$ & $<47$ & $<64$ & 131 & $<64$ & 110 \\
\hline Cs & $<0.18$ & $<0.16$ & 0.285 & 2.930 & 0.22 & 5.04 \\
\hline $\mathrm{Ba}$ & $<71$ & $<71$ & $<142$ & 544 & $<87$ & $<172$ \\
\hline $\mathrm{Hf}$ & $<0.10$ & $<0.10$ & 1.76 & 3.92 & 0.32 & 0.38 \\
\hline $\mathrm{Ta}$ & $<0.07$ & $<0.08$ & 0.26 & 1.14 & $<0.09$ & $<0.20$ \\
\hline Th & $<0.12$ & $<0.14$ & 1.91 & 10.26 & 0.25 & $<0.30$ \\
\hline $\mathrm{U}$ & $<0.57$ & $<0.81$ & 0.82 & 2.21 & 0.78 & $<1.52$ \\
\hline As & $<0.5$ & 26.8 & 21.9 & 26.5 & 13.6 & 38.7 \\
\hline $\mathrm{Sb}$ & $<0.08$ & 16.93 & 3.63 & 1.98 & 3.39 & 4.27 \\
\hline $\mathrm{La}$ & 0.50 & 0.45 & 9.08 & 33.24 & 2.42 & 3.51 \\
\hline $\mathrm{Ce}$ & 19.12 & 35.15 & 16.75 & 63.98 & 43.81 & 134.36 \\
\hline Nd & $<6.60$ & $<8.32$ & 5.61 & 21.39 & $<8.55$ & $<15.85$ \\
\hline $\mathrm{Sm}$ & 0.04 & 0.04 & 1.64 & 4.76 & 0.65 & 0.68 \\
\hline Eu & $<0.02$ & 0.06 & 0.60 & 1.02 & 0.17 & 0.21 \\
\hline $\mathrm{Tb}$ & $<0.11$ & $<0.11$ & 0.37 & 0.71 & 0.19 & $<0.25$ \\
\hline Dy & $<0.70$ & $<0.45$ & 1.53 & 3.78 & 0.52 & 0.63 \\
\hline $\mathrm{Yb}$ & 0.15 & $<0.16$ & 1.33 & 1.92 & 0.66 & 0.92 \\
\hline $\mathrm{Lu}$ & $<0.03$ & $<0.04$ & 0.15 & 0.26 & 0.08 & 0.13 \\
\hline
\end{tabular}

Fig. 8). The sample from the disseminated sulfide-bearing zone in the eastern gabbro hill $(\mathrm{H} / 48)$ with $\sim 1-2 \%$ (vol.) sulfides contains an anomalously high abundance of $\mathrm{Pd}(0.73 \mathrm{ppm})$ and $\mathrm{Ag}(0.14 \mathrm{ppm})$, but only trace amounts of Pt $(0.02 \mathrm{ppm})$ and $\mathrm{Au}(0.01 \mathrm{ppm})$. The sample of a fragment of massive chromitite from the Shankar lode (NF/14/SNK) and one each from the Durga lode (massive chromitite band: $\mathrm{O} / 1$ ) and Laxmi 2 lode (massive chromitite band: $\mathrm{O} / 2$ ) contain traces of noble metals (Table 4, Fig. 8). The two samples from the orthopyroxenite unit at the footwall of the breccia zone also contain traces of noble metals. Nickel, Co, and $\mathrm{Cu}$ show their maximum concentration $(1 \% \mathrm{Ni}$, $2.5 \% \mathrm{Cu}$, Table 4 ) in the chromite-sulfide assemblage of the breccia zone (NF/12/SNK/C), whereas the highest concentration of $\mathrm{V}$ and $\mathrm{Zn}$ are found in the gabbroic rock (sample NF/13/SNK). The samples of gabbroic rock also contain high concentrations of $\mathrm{Ni}$ and $\mathrm{Cu}$ (up to $0.2 \%$ and $1.3 \%$, respectively). 


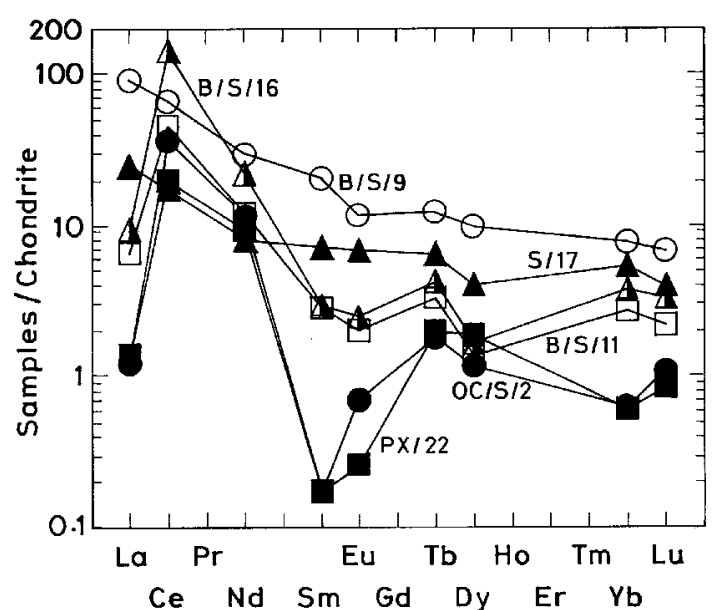

FIG. 7. Chondrite-normalized REE pattern for various rocks of the Breccia Zone and the adjacent area, Nuasahi chromite belt, Orissa, India. Samples: PX/22: orthopyroxenite, footwall of breccia zone, OC/S/2: serpentinite, breccia zone; S/17: eastern gabbro; B/S/9: quartz diorite, breccia zone; B/S/11: sulfide-rich assemblage, breccia zone; B/S/16: sulfide-rich gabbroic assemblage, hanging wall of the breccia zone.

\section{Discussion ANd Significance of Observations}

Intense mining activity in the Nuasahi complex has taken place during the last four decades and has resulted in significant new exposures of the lithological units, their contacts, disposition and other characters, all of which contribute to a greater geological understanding of the area. The idea of vein-type and shear-zone filling chromite mineralization in the area (Chakraborty 1958) is no longer viable, nor is the concept of a hydrothermal origin of chromite mineralization (Varma 1964). We have found that faulting and shearing are post-kinematic with respect to chromite mineralization, and that the ore bands were later folded, sheared and faulted. Mondal (2000) applied whole-rock and mineral compositions to show that the Nuasahi complex resembles an Archean greenstone-belt-hosted ultramafic-mafic complex. Available field observations suggest that the chromiferous ultramafic suite (Suite 1) formed a highly tectonized interlayered sequence prior to emplacement of the Suite 2 gabbro and formation of the breccia zone at its eastern part. We suggest that the emplacement of gabbro occurred in a late synkinematic phase of the deformation that produced the breccia zone within a shear zone.

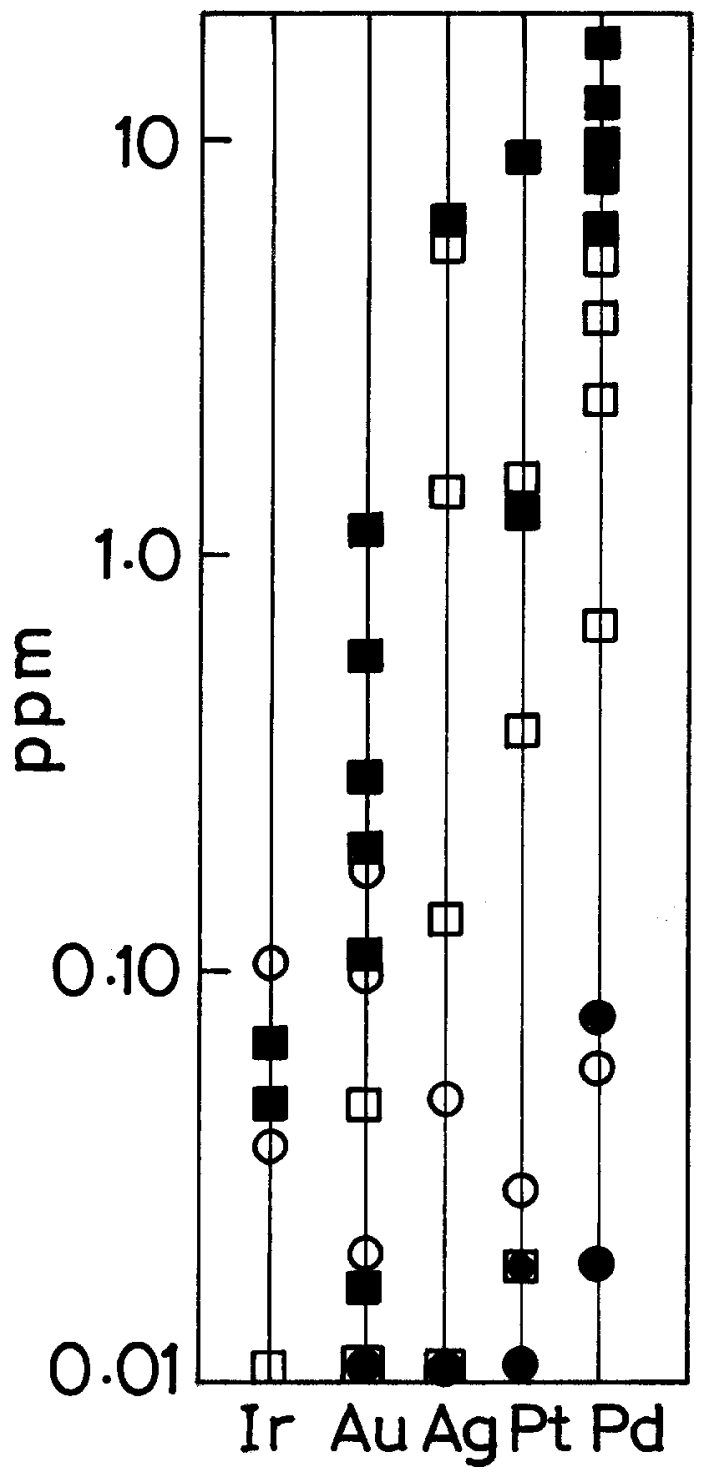

FIG. 8. Noble metal concentration in various rocks of the Nuasahi Complex. Filled circles: orthopyroxenite, footwall of breccia zone; open circles: massive chromitite bands; filled squares: chromite-sulfide assemblage of the breccia zone; open squares: sulfide-rich gabbroic rocks, hangingwall of the breccia zone.

\section{Chromian spinel}

The chemical compositions of magnesiochromite from the four chromite lodes display limited variation and are highly refractory in composition $(0.78<\mathrm{Cr} \#<$ $0.81,0.71<\mathrm{Mg} \#<0.80$; Fig. 6), indicating a similar 
TABLE 4. PGE AND TRACE-ELEMENT CONTENT OF VARIOUS ROCKS, NUASAHI ULTRAMAFIC-MAFIC COMPLEX, ORISSA, INDIA

\begin{tabular}{|c|c|c|c|c|c|c|c|c|c|c|c|c|c|c|c|c|c|c|c|}
\hline Sample & Rock type & Technique & $\mathrm{Pt}$ & $\mathbf{P d}$ & $\mathrm{Ir}$ & $\mathrm{Au}$ & $\mathrm{Ag}$ & $\mathrm{Cu}$ & $\mathrm{Ni}$ & $\mathrm{Co}$ & $\mathrm{Pb}$ & $\mathrm{Zn}$ & $\mathrm{V}$ & $\mathrm{Te}$ & $\mathrm{Sb}$ & $\mathrm{Bi}$ & As & Mo & $\mathrm{Cd}$ \\
\hline L/57 & $\begin{array}{l}\text { Orthopyroxenite } \\
\text { (serpentinized) } \\
\text { hanging wall }\end{array}$ & 1 & 0.01 & 0.02 & - & $<0.01$ & $<0.01$ & 169 & 640 & 71 & 14 & 54 & 106 & - & - & - & - & - & - \\
\hline $\begin{array}{l}\mathrm{NF} / 15 / \\
\mathrm{SNK}\end{array}$ & $\begin{array}{l}\text { Orthopyroxenite } \\
\text { (serpentinized) } \\
\text { hanging wall }\end{array}$ & 1 & 0.02 & 0.08 & - & 0.01 & $<0.01$ & 110 & 540 & 104 & 2 & 39 & 114 & 1 & 1 & 0.07 & 33 & 0.29 & $<0.01$ \\
\hline $\begin{array}{l}\mathrm{NF} / 14 / \\
\mathrm{SNK}\end{array}$ & $\begin{array}{l}\text { Shankar chromite } \\
\text { lode, Breccia Zone }\end{array}$ & 1 & 0.03 & 0.06 & - & $<0.01$ & 0.05 & 45 & 835 & 17 & 16 & 75 & 98 & 0.21 & 172 & 0.19 & 62 & 0.55 & $<0.01$ \\
\hline $\begin{array}{l}\mathrm{NF} / 12 / \\
\mathrm{SNK} / \mathrm{C}\end{array}$ & $\begin{array}{c}\text { Chromite-sulfide } \\
\text { assemblage } \\
\text { ( } \sim 40 \% \text { sulfide }) \\
\text { Breccia Zone }\end{array}$ & 1 & 1.37 & 8.81 & - & 0.31 & 6.63 & $2.5 \%$ & $1 \%$ & 335 & 22 & 120 & 356 & 3 & 6 & 1 & 31 & 1 & 5 \\
\hline $\begin{array}{l}\mathrm{NF} / 13 / \\
\mathrm{SNK}\end{array}$ & $\begin{array}{l}\text { Gabbroic rock } \\
(\sim 5 \% \text { sulfide) } \\
\text { hanging wall, } \\
\text { Breccia Zone }\end{array}$ & 1 & 1.55 & 2.51 & - & 0.05 & 1.54 & $0.5 \%$ & $0.2 \%$ & 168 & 5 & 247 & 491 & 2 & 4 & 0.52 & 170 & 0.42 & 0.78 \\
\hline FCS/14 & $\begin{array}{l}\text { Gabbroic rock } \\
\text { ( } 3 \% \text { sulfide) } \\
\text { hanging wall } \\
\text { Breccia Zone }\end{array}$ & 1 & 0.40 & 4.06 & - & 0.18 & 6 & $1.3 \%$ & $0.13 \%$ & 87 & 7 & 44 & 120 & 3 & 2 & 0.74 & 35 & 0.76 & 2 \\
\hline H/48 & $\begin{array}{c}\text { Hill Gabbro } \\
\text { with disseminated } \\
\text { sulfides }\end{array}$ & 1 & 0.02 & 0.73 & - & 0.01 & 0.14 & 192 & 251 & 50 & 8 & 104 & 208 & 1 & 0.58 & 0.09 & 42 & 0.75 & 0.08 \\
\hline $\begin{array}{l}\text { SARM } \\
7\end{array}$ & $\begin{array}{c}\text { South African } \\
\text { Bureau of Standards } \\
\text { (SABS), Platinum Ore }\end{array}$ & 1 & $\begin{array}{c}3.98 \\
(3.74)\end{array}$ & $\begin{array}{c}1.50 \\
(1.53)\end{array}$ & - & $\begin{array}{c}0.45 \\
(0.31)\end{array}$ & $\begin{array}{c}0.53 \\
(0.42)\end{array}$ & - & - & - & - & - & - & - & - & - & - & - & - \\
\hline $\begin{array}{l}\text { PTM } \\
1\end{array}$ & $\begin{array}{l}\text { Matte produced from } \\
\text { Sudbury ore }\end{array}$ & 1 & $\begin{array}{l}5.79 \\
(5.8)\end{array}$ & $\begin{array}{l}12.83 \\
(8.1)\end{array}$ & - & $\begin{array}{l}1.77 \\
(1.8)\end{array}$ & $\begin{array}{c}65.53 \\
(66)\end{array}$ & & - & - & - & - & - & - & - & - & - & - & - \\
\hline $\mathrm{CH} 1$ & $\begin{array}{l}\text { Cu-Ag-Au-bearing } \\
\text { sulfide ore }\end{array}$ & 1 & - & 0.09 & - & $\begin{array}{c}0.21 \\
(0.24)\end{array}$ & 16.31 & - & - & - & - & - & - & - & - & - & - & - & - \\
\hline $\mathrm{NS} / 1$ & $\begin{array}{c}\text { Chromite-sulfide } \\
\text { assemblage } \\
\text { Breccia Zone }\end{array}$ & 2 & ND & 11.82 & $\begin{array}{l}0.35 \\
\text { ppb }\end{array}$ & $\begin{array}{l}18.5 \\
\mathrm{ppb}\end{array}$ & $\begin{array}{l}5.84 \\
\mathrm{ppb}\end{array}$ & - & - & - & - & - & - & - & - & - & - & - & - \\
\hline $\mathrm{NS} / 2$ & $\begin{array}{l}\text { Sulfide-rich gabbroic } \\
\text { rock, hanging wall, } \\
\text { Breccia Zone }\end{array}$ & 2 & 1.56 & 5.52 & $\begin{array}{l}0.07 \\
\mathrm{ppb}\end{array}$ & $\begin{array}{l}4.51 \\
\mathrm{ppb}\end{array}$ & $\begin{array}{l}0.39 \\
\mathrm{ppb}\end{array}$ & - & - & - & - & - & - & - & - & - & - & - & - \\
\hline $\mathrm{NS} / 3$ & Same as NS/1 & 2 & ND & 6.24 & - & - & - & - & - & - & - & - & - & - & - & - & - & - & - \\
\hline $\mathrm{NS} / 4$ & $\begin{array}{l}\text { Chromite-sulfide } \\
\text { assemblage, } \\
\text { Breccia Zone }\end{array}$ & 2 & 9.59 & 9.46 & $\begin{array}{l}2.77 \\
\mathrm{ppb}\end{array}$ & $\begin{array}{l}110 \\
\mathrm{ppb}\end{array}$ & $\begin{array}{l}9.59 \\
\mathrm{ppb}\end{array}$ & - & - & " & - & - & - & - & - & - & - & - & - \\
\hline $\mathrm{B} / \mathrm{O} / 4$ & same as NS/4 & 3 & - & 12 & 0.05 & 0.2 & - & - & - & - & - & - & - & - & - & - & - & - & - \\
\hline $\begin{array}{l}\text { NF/12/ } \\
\text { SNK/C }\end{array}$ & same as NS/4 & 3 & - & 6.1 & - & 0.61 & - & - & - & - & - & - & - & - & - & - & - & - & - \\
\hline $\mathrm{FCS} / 7$ & same as NS/4 & 3 & - & 17.9 & 0.07 & 1.22 & - & - & - & - & - & $=$ & - & - & - & - & - & - & - \\
\hline $0 / 1$ & $\begin{array}{l}\text { Durga chromite lode, } \\
\text { massive chromitite band }\end{array}$ & 3 & - & ND & 0.11 & 0.10 & - & - & - & - & - & - & - & - & - & - & - & - & - \\
\hline $\mathrm{O} / 2$ & $\begin{array}{l}\text { Laxmi- } 2 \text { chromite lode, } \\
\text { massive chromitite band }\end{array}$ & 3 & - & $\mathrm{ND}$ & 0.04 & 0.02 & - & - & - & - & - & - & - & - & - & - & - & - & - \\
\hline
\end{tabular}

ND: not detected; (-): not determined. Samples CH1, PTM1 and SARM7 are standard samples. Recommended values are given in parentheses (95\% confidence interval). Analytical techniques: 1 inductively coupled plasma - mass spectrometry, 2 Pb-button fire assay followed by atomic absorption spectrometry for $\mathrm{Pt}$ and $\mathrm{Pd}$, and instrumental neutron-activation analysis for $\mathrm{Ir}, \mathrm{Ag}$ and $\mathrm{Au}, 3 \mathrm{RNNA}$. Results are expressed in parts per million except where noted.

parental magma to each lode. Extensive alteration during serpentinization accompanied by $\mathrm{CO}_{2}$ activity produced the rims of ferrian chromite and magnetite around the chromian spinel, as well as dusty trails of these phases in the serpentinized matrix. The chromian spinel in sulfide-mineralized areas is dominantly of ferrian chromite type (Fig. 6) and interpreted to be the alteration product of pre-existing chromite that now contains several types of inclusions. The low-temperature alter- ation and metamorphism seem to be a more or less continuous process of re-equilibration and replacement of chromite by magnetite (Barnes 2000). The $\mathrm{Cr}$ fixed in chromian spinel by early magmatic processes may be remobilized by subsolidus rock-fluid interaction (e.g., Pan \& Fleet 1989), and ferrian chromite is a common intermediate product of alteration. The ferrian chromite in sulfide-rich assemblages of the breccia zone in Nuasahi was already altered owing to serpentinization 
of the ultramafic suite and again chemically modified during crystallization of the sulfide mineralization. It is possible that such chromite was completely transformed to ferrian chromite as a result of subsolidus re-equilibration between base-metal sulfides and silicates (both included and interstitial varieties) with chromite, as described by Naldrett \& Lehmann (1987). Among the $B M S$ inclusions in ferrian chromite, chalcopyrite is the dominant phase. This may be due to the above process, i.e., $B M S$ lost its $\mathrm{Fe}$ and became relatively enriched in $\mathrm{Cu}$. Exsolved lamellae in some oxide mineral inclusions (Fig. 4d) in coarser-grained ferrian chromite indicate the multistage unmixing of these phases. It has been observed that the most magnesian compositions of

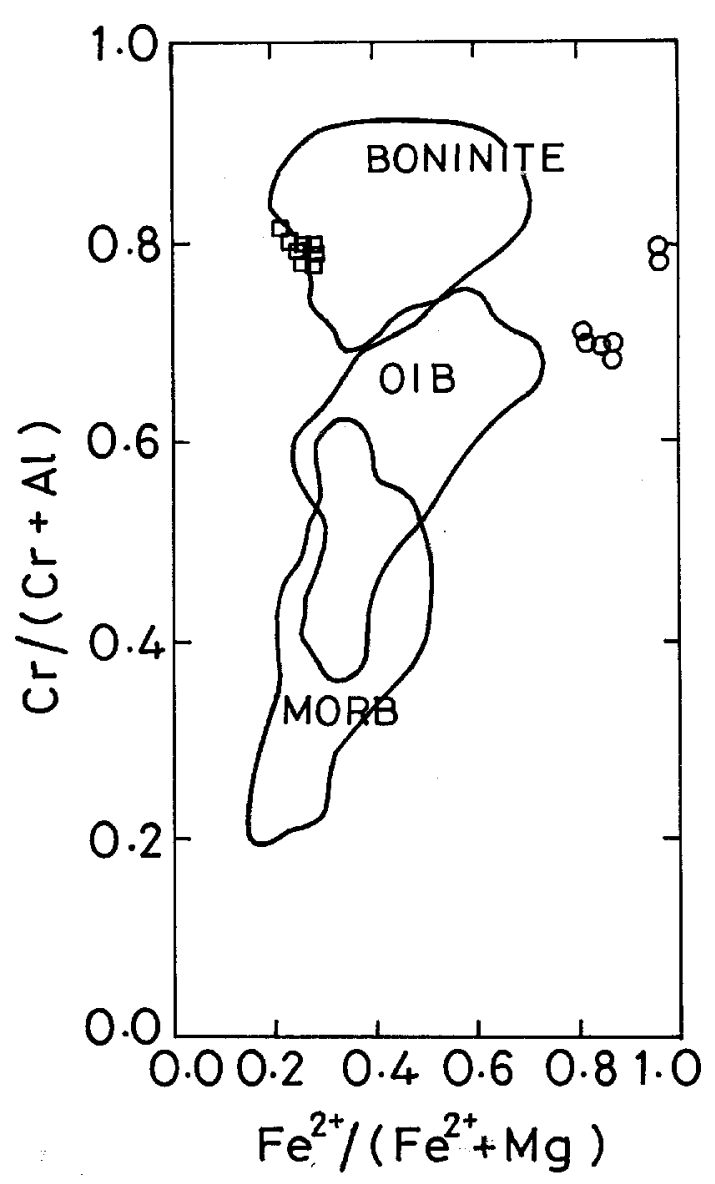

FIG. 9. Plot showing compositional fields of chromian spinels from boninitic basalts, ocean-island basalts (OIB) and midocean-ridge basalts (MORB) in term of $\mathrm{Cr} /(\mathrm{Cr}+\mathrm{Al})$ versus $\mathrm{Fe}^{2+} /\left(\mathrm{Fe}^{2+}+\mathrm{Mg}\right)$. Open squares represent compositions of chromian spinel from massive chromitite bands of the Nuasahi Complex. Open circles represent ferrian chromite compositions of chromite-sulfide assemblage in the breccia zone (after Roeder 1994). chromian spinel are usually associated with magnesian olivine in primitive basaltic rocks, mantle peridotites and chromitites (Roeder 1994) (Fig. 6, Field I). In a plot of $\mathrm{Cr} /(\mathrm{Cr}+\mathrm{Al})$ versus $\mathrm{Fe}^{2+} /\left(\mathrm{Fe}^{2+}+\mathrm{Mg}\right)$ of the chromian spinel compositions, the concentration at the upper right of Figure 6 (Field II) is due to magnetite from metamorphic rocks. Those compositions that fall in the lower right corner of Figure 6 (Field III) are due to magnetite found in fresh igneous rocks (Roeder 1994). Aluminous spinel, i.e., low $\mathrm{Cr} /(\mathrm{Cr}+\mathrm{Al})$, and igneous magnetite, i.e., aluminates and ferrites, show limited solid-solution at the temperatures found in nature (Sack \& Ghiorso 1991) and it becomes quite limited under metamorphic conditions. The chromian spinel compositions from the sulfide-rich portion of the breccia zone concentrate at the upper right part of the $\mathrm{Cr} /(\mathrm{Cr}+\mathrm{Al})$ versus $\mathrm{Fe}^{2+}$ / $\left(\mathrm{Fe}^{2+}+\mathrm{Mg}\right.$ ) plot (Fig. 6), and correspond to reworked chromite, now represented by ferrian chromite. The magnesiochromite in massive chromitite band with low $\mathrm{Fe}^{2+}$ values may represent the liquidus composition of chromian spinel because of the large amount of chromite relative to the amount of silicate. The limited chance for subsolidus re-equilibration makes it a useful indicator of magmatic conditions at the time of initial crystallization (Roeder 1994). It has been shown that chromian spinel from boninites has the highest $\mathrm{Cr} \#$ value (Roeder 1994). The magnesiochromite in massive chromitite bands from the Nuasahi complex concentrates in the boninite field (Fig. 9). In a plot of the trivalent cations $\mathrm{Cr}-\mathrm{Al}-\mathrm{Fe}^{3+}$, the chromite compositions in the massive chromitite bands at Nuasahi concentrate in the residual peridotite/ophiolite field (Fig. 10). The oriented lamellae of chlorite in ferrian chromite of the sulfide mineralized zones of the Nuasahi complex favor the hypothesis of the alteration of chromite in this setting.

\section{Platinum-group minerals and base-metal sulfides}

Silicate mineral inclusions in chromian spinel are of interest because of their possible linkage to the primary or early magmatic origin of the $\mathrm{Ni}-\mathrm{Cu}$ sulfides and platinum-group minerals associated with chromian spinel (e.g., Lorand \& Cottin 1987, Lorand \& Ceuleneer 1989, McElduff \& Stumpfl 1990, Fleet et al. 1993). PGM inclusions reported in chromian spinel are typically Ir-, Os-, Ru-bearing alloys, sulfides and Pt-alloys, which are commonly subhedral to euhedral. In the present occurrence, PGM are mostly Pd-bearing (sudburyite mainly) and are possibly the first report as inclusions in chromian spinel. Pd-bearing PGM inclusions in chromian spinel are only reported from a few locations (e.g., Talkington \& Lipin 1986). Merkle (1992) reported a Pt-Pd-As-Sb phase in chromian spinel along with idiomorphic laurite from the MG-IB chromitite layer of the Middle group from the Bushveld complex. He described other Ru-Os$\mathrm{Ni}-\mathrm{As}-\mathrm{S}$ phases and a Ni-Ru-Os-S-As phase and postulated the existence of Pt-Pd-Ru-Os-As-Sb-S melt (or high-temperature phase) with some Ir and Fe. In 


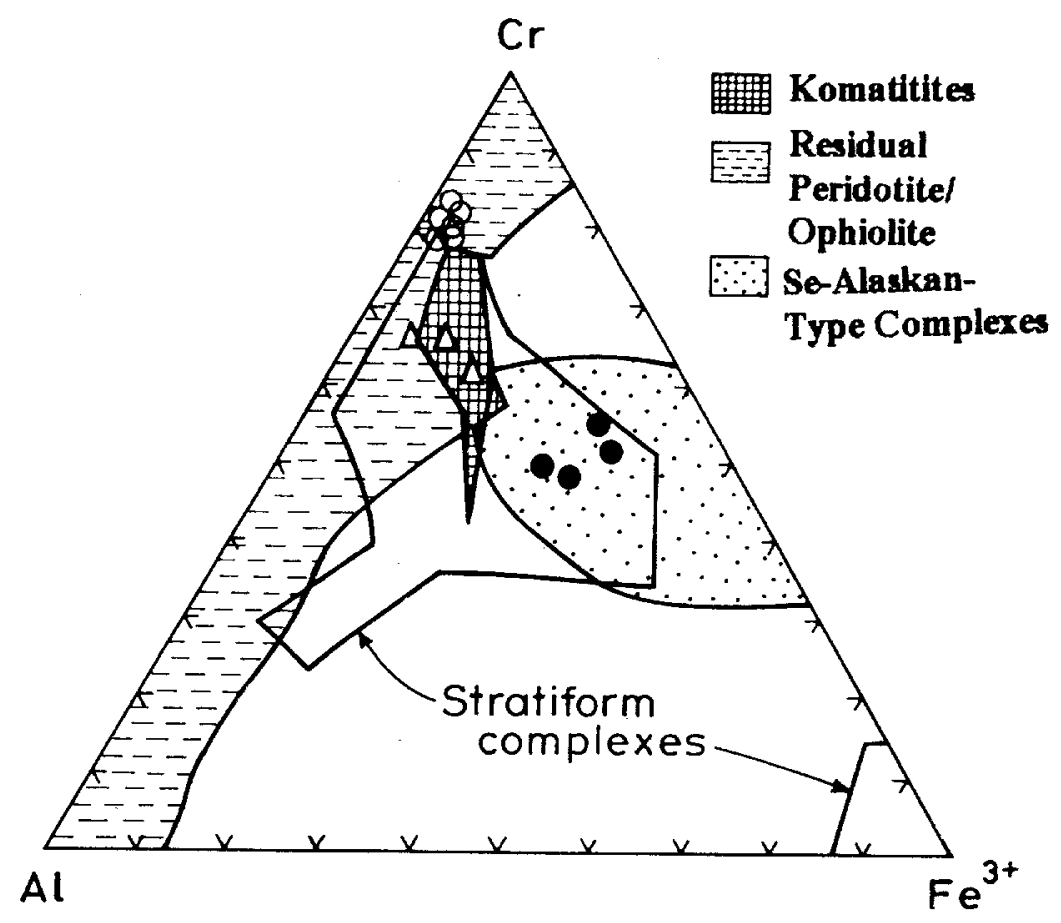

FIG. 10. $\mathrm{Cr}-\mathrm{Al}-\mathrm{Fe}^{3+}$ plot of chromian spinel form the Nuasahi Complex. Open circles: compositions of chromian spinel from massive chromitite bands, open triangles: coarser-grained ferrian chromite from the sulfide-rich breccia zone, and filled circles: finer-grained ferrian chromite in sulfide-rich assemblages of the breccia zone (both chromite-sulfide assemblage and gabbroic rocks at the hanging-wall portion of the breccia zone). The various fields are after Jan \& Windley (1990).

some cases, the PGM are included in ferrian chromite (e.g., McElduff \& Stumpfl 1990) and believed to be secondary in origin. Orthomagmatic models for PGE deposits suggest that Ru-, Ir- and Os-bearing minerals in particular, laurite and Pt-alloys are precipitated at high temperature and are commonly found as inclusions in chromian spinel or olivine (Barnes et al. 1985). In contrast, lower-temperature PGE-mineralization is usually Pd- and Pt-rich and occurs in association with disseminated sulfides. Platinum-group minerals in chromitesulfide assemblages of the breccia zone in the Nuasahi complex are in general associated with $B M S$ and, therefore, they are genetically related to a sulfide liquid. The close association between the PGE and BMS mineralization in this area is also depicted by the $\mathrm{Cu}-\mathrm{Pd}$ correlation in Figure 11 and also shown by Augé et al. (1999; Fig. 2). Among the sulfide minerals, the high-reflectance variety of pyrrhotite has crystallized earlier than the other $B M S$. Petrographic and mineralogical studies of the sulfide-mineralized zone shows that cobaltitegersdorffite (with included irarsite-hollingworthite) and several $\mathrm{Pd}-\mathrm{Sb}-\mathrm{Bi}-\mathrm{Te}$ phases have crystallized prior to interstitial chalcopyrite, pyrrhotite and pyrite. This in- dicates that the sulfide melt was initially enriched with $\mathrm{Ni}, \mathrm{Co}, \mathrm{Sb}, \mathrm{Bi}, \mathrm{Te}$, and PGE, and that the concentrations of these metals gradually decreased with falling temperature, giving rise to the crystallization of $\mathrm{Fe}-\mathrm{Cu}-$ rich sulfides. Palladium antimonides and tellurides are found in mineral assemblages of early crystallization as well as in late-stage hydrothermal environments, and the system covers a temperature range of $600-1000^{\circ} \mathrm{C}(\mathrm{Kim}$ \& Chao 1991). The phase chemistry of platinum bismuthinides, bismutotellurides and tellurides (Cabri 1981) suggests that they should decompose at relatively low temperatures and thus be available for transport, even at conditions of moderately low-grade metamorphism. Their genesis has been attributed either to late magmatic fractionation of the PGE (Cabri \& Laflamme 1976, Skinner et al. 1976) or to remobilization of the PGE during a later hydrothermal stage (e.g., Ballhaus \& Stumpfl 1986).

\section{$P G E$ and sulfide mineralization: genetic model}

The limited analytical data for noble metals show high tenors for the PGE and Ag (Fig. 8) for sulfide-rich 


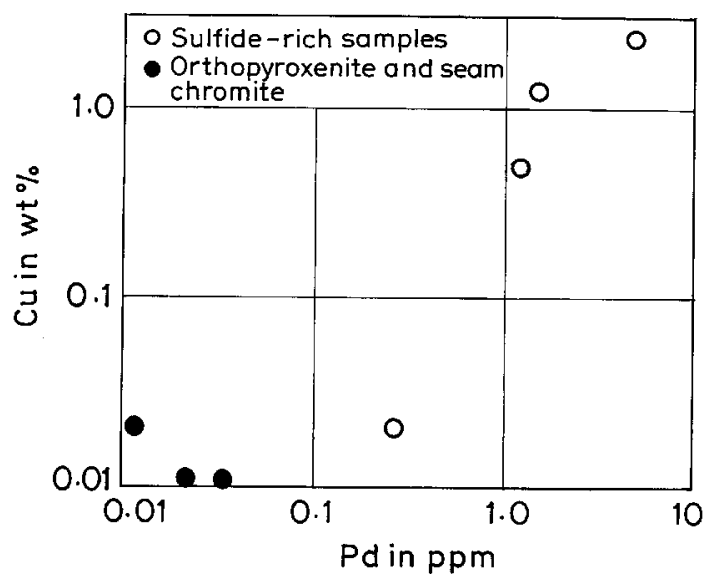

FIG. 11. $\mathrm{Cu}-\mathrm{Pd}$ correlation diagram to show the relationships between the noble metal and base-metal sulfides mineralization in the Nuasahi Complex.

samples of the breccia zone, with variable Pd:Pt values and $\mathrm{Au}$ content, which has significance from the economic point of view. This high noble-metal tenor is comparable to that in the well-known PGE deposits of world. We observe that high PGE tenor is correlated with high $B M S$ content of the rocks of the breccia zone. Moreover, ferrian chromite constitutes a significant phase in these sulfide-rich assemblages where the noble metal tenor is high. The most significant difference between the typical PGE-bearing layered complexes or ophiolitic complexes and the Nuasahi occurrence is the lack of continuity between ultramafic and gabbroic suites. Gabbro is distinctly discordant to the ultramafic suite, and intruded the latter. The sulfide mineralization in the breccia zone is irregularly distributed, and the concentrations vary laterally, longitudinally and also with depth. The REE patterns (Fig. 7) also reflect the heterogeneous lithological makeup of the breccia zone and support the argument that the mafic and ultramafic rocks are not necessarily genetically related by fractional crystallization. The structural relations between ultramafic and mafic units are such that a genetic relationship by fractional crystallization cannot necessarily be assumed. Hence, the sulfide-rich character of the gabbro units cannot be attributed to the formation of ultramafic rocks.

Our hypothesis involves specific temporal relationships between crystallization of the complex, brecciation and deformation of the ultramafic units and intrusion of the gabbroic suite. We consider that the gabbroic suite is not the product of fractional crystallization of a magma that produced the ultramafic rocks as initial cumulates. We observe that the sulfide mineralization is present in the gabbroic rocks adjacent to the hanging-wall of the breccia zone and also in the middle portion of the gabbroic suite on the eastern side. The gabbro thus is possibly the main contributor of sulfides in this mineralized complex. Platinum-group minerals in the chromite-sulfide assemblage of the breccia zone are not compositionally like the PGM normally associated with chromite. The proportion of the PGE is distinctive and highly evolved in nature. Such a PGE pattern is usually attributed to fractional crystallization of a sulfide-rich melt at magmatic temperatures accompanied by the removal of iron sulfides and separation in a Cu-rich sulfide liquid (Skinner et al. 1976, Cabri \& Laflamme 1976). Unless the earlier assemblage assimilated by the gabbroic magma included PGE of this highly evolved nature, the gabbro itself should be rather evolved. We conclude that the ultramafic portion was already serpentinized and may have contained some PGM (Ir-group PGM mainly) and sulfides, which were incorporated by the gabbroic magma. The only suggestion that the chromite-bearing ultramafic rocks are the source of any of the mineralization is the presence of irarsite-hollingworthite. In general, the gabbro-brecciahosted PGE mineralization in the Nuasahi complex is not dominated by Ir, Os or Ru mineralization, but rather by Pd-Pt mineralization. The mineralized rocks of the breccia zone have an intermediate chemical composition, as is evident from chemical data (Table 3 ) and REE patterns (Fig. 7), which support the assimilation and production of a hybrid liquid. The variable but locally elevated $\mathrm{Ag}$ contents in the mineralized rocks indicate the contamination of this liquid by country rock. Ferrian chromite in the chromite-sulfide assemblage of the breccia zone shows an increase of $\mathrm{Fe}, \mathrm{Ti}, \mathrm{V}, \mathrm{Mn}$ and a decrease of $\mathrm{Cr}, \mathrm{Mg}$ and $\mathrm{Al}$ content. Merkle (1987) showed that metasomatism of chromite from the UG1 chromitite layer of the Bushveld complex caused the spinel composition to become enriched in $\mathrm{Fe}, \mathrm{Ti}, \mathrm{V}$, and $\mathrm{Mn}$, and depleted in $\mathrm{Mg}, \mathrm{Al}$ and $\mathrm{Cr}$. Of perhaps greater relevance here is the observed metasomatism of upper mantle peridotites by younger gabbroic magma in the Zambales ophiolite (Evans 1985). The metasomatism produced large relative enrichment in lithophile elements $(\mathrm{Na}, \mathrm{Ca}, \mathrm{Al}, \mathrm{Ti}$, and $\mathrm{K})$ in the contact zone. The concentration of these elements (particularly $\mathrm{Na}, \mathrm{K}, \mathrm{Ti}$, $\mathrm{Al}, \mathrm{Ca}$ and $\mathrm{Fe}$ ) is also enriched in both matrix of the mineralized breccia zone and the gabbro at the hanging-wall part. Furthermore, ferrian chromite at the margins of chromitite fragments in the gabbroic matrix contains inclusions of rutile, and ferrian chromite in the matrix part of the sulfide-rich portion of the breccia zone is extensively replaced by sulfides. We conclude that metasomatism of pre-existing chromite (and ultramafic rocks) was caused by injection of gabbroic magma into the breccia zone, concomitant with development of the PGE and sulfide mineralization. Inclusions in coarsergrained chromite were probably formed during coalescence and subsequent fusion together of fragmented and granulated chromite (also altered) within the sulfide-rich magma at a relatively high temperature. 


\section{ACKNOWLEDGEMENTS}

Financial assistance to SKM as Research Fellowship (1994-1997) by the CSIR, Government of India, is gratefully acknowledged. The FACOR Ltd., OMC Ltd. and IMFA Ltd. extended their cooperation and logistical support during the geological fieldwork in the area by SKM. Our sincere thanks to James H. Crocket and Robert F. Martin for their useful suggestions in reviews of this paper. Thanks are also due to the Director USIC, and Dr. T.K. Ghosh, University of Roorkee, for their kind cooperation during the analytical work. The Director, BARC and Head, Analytical Chemistry Division, BARC are acknowledged for their kind permission to carry out NAA work in collaboration with Dr. Rakesh Verma of Analytical Chemistry Laboratory. Our sincere thanks to Dr. Rakesh Verma for RNAA data and collaboration throughout this work.

\section{REFERENCES}

Augé, T., Salpeteur, I., Mukherjee, M.M. \& Patra, R.N. (1999): Platinum-group element mineralization in the breccia zone of the Baula Nuasahi Complex, Orissa, India. In Mineral Deposits: Processes to Processing (C.J. Stanley and 39 others, eds.). Balkema, Rotterdam, The Netherlands (1468).

Balaram, V., Hussain, S.M., Raj, B.U., Charan, S.N., Subba RaO, D.V., ANJaiah, K.V., Ramesh, S.L. \& Ilangovan, S. (1997): Determination of gold, platinum, palladium, and silver in rocks and ores by ICP-MS for geochemical exploration studies. Atom. Spect. 18, 17-22.

Ballhaus, C.G. \& StumpFl, E.F. (1986): Sulfide and platinum mineralization in the Merensky Reef: evidence from hydrous silicates and fluid inclusions. Contrib. Mineral. Petrol. 94, 193-204.

BARnEs, S.-J., NAldretT, A.J. \& Gorton, M.P. (1985): The origin of the fractionation of platinum-group elements in terrestrial magmas. Chem. Geol. 53, 303-323.

BARNES, S.J. (2000): Chromite in komatiites. II. Modification during greenschist to mid-amphibolite facies metamorphism. J. Petrol. 14, 387-409.

CABRI, L.J., ed. (1981): Platinum-Group Elements: Mineralogy, Geology, Recovery. Can. Inst. Mining Metall., Spec. Vol. 23.

\& LAFLAMME, J.H.G. (1976): The mineralogy of the platinum-group elements from some copper-nickel deposits of the Sudbury area, Ontario. Econ. Geol. 71, 11591195 .

ChaKraborty, K.L. (1958): Chromite ores associated with ultrabasic rocks of Nuasahi, Keonjhar district, Orissa, India. Proc. Nat. Inst. Sci. India 24A, 78.

Deb, S. \& Chakraborty, K.L. (1960): Trend of differentiation in the gabbro-anorthosite suite of rocks of Nuasahi,
Keonjhar district, Orissa, India. Proc. Nat. Inst. Sci. India 26, 420-435.

Droop, G.T.R. (1987): A general equation for estimating $\mathrm{Fe}^{3+}$ concentrations in ferromagnesian silicates and oxides from microprobe analyses, using stoichiometric criteria. Mineral. Mag. 51, 431-435.

Evans, C. (1985): Magmatic 'metasomatism' in peridotites from the Zambales ophiolite. Geology March, 166-169.

Fleet, M.E., Angeli, N. \& Pan, Yuanming (1993): Oriented chlorite lamellae in chromite from the Pedra Branca maficultramafic complex, Ceara, Brazil. Am. Mineral. 78, 68-74.

Hafty, J., Riley, L. B. \& Gross, W. D. (1977): A manual on fire assaying and determination of the noble metals in geological materials, U.S. Geol. Surv. Bull. 1445.

HaLdAR, D. (1967): Some observations on the chromiferous ultramafic and the associated rocks around Nuasahi, Keonjhar district, Orissa. Indian Minerals 21, 196-204.

JAN, M.Q. \& WindLEY, B.F. (1990): Chromian-spinel - silicate chemistry in ultramafic rocks of the Jijal complex, northwest Pakistan. J. Petrol. 31, 667-715.

KIM, W.S. \& CHAO, G.Y. (1991): Phase relations in the system Pd-Sb-Te. Can. Mineral. 29, 401-409.

Kumar, S., Verma, R. \& Gangadharan, S. (1993): Application of poly (aniline) as an ion exchanger for the separation of palladium, platinum and gold prior to their determination by neutron activation analysis. Analyst 18, 1085-1087.

LORAND, J.P. \& CEUlENEER, G. (1989): Silicate base-metal sulfide inclusions in chromites from the Maqsad area (Oman ophiolite, Gulf of Oman): a model for entrapment. Lithos 22, 173-190.

\& CotTin, J.Y. (1987): Na-Ti-Zr-- $\mathrm{H}_{2} \mathrm{O}-$ rich mineral inclusions indicating postcumulus chrome-spinel dissolution and recrystallization in the western Launi mafic intrusion, Algeria. Contrib. Mineral. Petrol. 97, 251-263.

McElduff, B. \& Stumpfl, E.F. (1990): Platinum-group minerals from the Troodos ophiolite, Cyprus. Mineral. Petrol. 42, 211-232.

MERKLE, R.K.W. (1987): The effects of metasomatising fluids on the PGE-content of the UG-1 chromitite layer. In GeoPlatinum ' 87 (H.M. Prichard, P.J. Potts, J.F.W. Bowles \& S.J. Cribb, eds.). Elsevier Applied Science, London, U.K. (359).

(1992): Platinum-group minerals in the middle group of chromitite layers at Marikana, western Bushveld Complex: indications for collection mechanisms and postmagmatic modification. Can. J. Earth Sci. 29, 209-221.

MoHANTY, J.K. \& SAHOO, R.K. (1989): Chemistry of chromites from Baula-Nuasahi igneous complex, Keonjhar district, Orissa and its petrogenetic significance. J. Geol. Soc. India 33, 161-170. 
Mondal, S.K. (2000): Study of Chromite, Sulfide and Noble Metal Mineralization in the Precambrian Nuasahi Ultramafic-Mafic Complex, Keonjhar district, Orissa, India. Ph.D. thesis, Jadavpur Univ., Calcutta, India.

\& BAIDYA, T.K. (1996): Stichtite $\left[\mathrm{Mg}_{6} \mathrm{Cr}_{2}(\mathrm{OH})_{16}\right.$ $\mathrm{CO}_{3} \bullet 4 \mathrm{H}_{2} \mathrm{O}$ ] in Nuasahi ultramafites, Orissa, India - its transformation at elevated temperatures. Mineral. Mag. 60, 836-840.

\& (1997): Platinum-group mineral from the Nuasahi ultramafic-mafic complex, Orissa, India. Mineral. Mag. 61, 902-906.

MUKHERJEE, S. (1962): Geology, mineralogy and geochemistry of the chromite deposits of Nuasahi, Keonjhar district, Orissa. J. Geol., Mining Metall. Soc. India 34(1), 29-45.

Naldrett, A.J. \& Lehmann, J. (1987): Spinel nonstochiometry as the explanation for Ni-, $\mathrm{Cu}$ - and PGE-enriched sulfides in chromitites. In Geo-Platinum '87 (H.M. Prichard, P.J. Potts, J.F.W. Bowles \& S.J. Cribb, eds.). Elsevier Applied Science, London, U.K. (93-110).

PAN, YuAnMing \& FleEt, M.E. (1989): Cr-rich calc-silicates from the Hemlo area, Ontario. Can. Mineral. 27, 565-577.

Roeder, P.L. (1994): Chromite: from the fiery rain of chondrules to the Kilauea Iki lava lake. Can. Mineral. 32, 729-746.
SACK, R.O. \& GHIORSO, M.S. (1991): Chromian spinels as petrogenetic indicators: thermodynamics and petrological applications. Am. Mineral. 76, 827-847.

SAHA, A.K. (1994): Crustal evolution of Singhbhum, NorthOrissa, eastern India. Geol. Soc. India, Mem. 27.

RAY, S.L. \& SARKAR, S.N. (1988): Early history of the Earth: evidence from the Eastern India Shield. Geol. Soc. India, Mem. 8, 13-37.

SkinNER, B.J., LuCE, F.D., Dill, J.A., Ellis, P.E., HAGAN, H.A., Lewis, D.M., Odell, D.A., SverJensky, D.A. \& Williams, N. (1976): Phase relationships in ternary portions of the system Pt-Pd-Fe-As-S. Econ. Geol. 71, 1469-1475.

TAlkington, R.W. \& LiPIN, B.R. (1986): Platinum-group minerals in chromite seams of the Stillwater Complex, Montana. Econ. Geol. 81, 1177-1186.

VArma, O.P. (1964): Chromite deposits of the Keonjhar districts, Orissa, India. Econ. Geol. 39, 799-825.

Received November 28, 2000, revised manuscript accepted May 2, 2001. 


\section{Appendix: Methodology}

Intense mining activities (both underground and open cut) by the three mining authorities during the last four decades have exposed almost all the rocks of the chromiferous ultramafic suite (Suite 1). For reconnaissance study, samples of the different rocks were collected from all three mine-areas and also from the gabbroic suite (Suite 2). Thin sections, polished thin sections and polished sections were prepared and studied under the microscope both in transmitted light and reflected light. Samples selected for the present study were mainly from the breccia zone and its adjacent rocks. Chromite grains and some included oxide phases were analyzed with a JEOL JXA-8600 superprobe at the University Science Instrumentation Center, University of Roorkee, India, under the following analytical conditions: acceleration voltage $15 \mathrm{kV}$, probe current $20 \mathrm{nA}$, beam diameter $2 \mu \mathrm{m}$ with SPI multi-standards, Canada. A few cobaltite-gersdorffite (cb-gd) grains from the chromite-sulfide assemblage of the breccia zone have been analyzed using the above-mentioned analytical conditions. Some of the cobaltite-gersdorffite grains have been analyzed by a Cambridge Leica Stereoscan 440 model Scanning Electron Microscope equipped with energy-dispersion spectrometry (EDS) with a SiLi detector. Resolution of the detector was $63 \mathrm{eV}$, and $\mathrm{ZAF}$ online data-corrections were used. These SEM-EDS data have been normalized to $100 \%$; these semiquantitative data permit the minerals to be identified.

The fresh samples of sulfide-bearing rocks from the breccia zone and its adjacent rocks, and also a few samples of chromite lodes, were pulverized to 300 mesh with a contamination-free RIGAKU mill in the Department of Geological Sciences, Jadavpur University, Calcutta. Six selected rock samples, mainly from the breccia zone and its adjacent footwall orthopyroxenite and hanging-wall gabbroic rock, have been analyzed by Instrumental Neutron activation Analysis (INAA) from the Research Reactor Center, University of Missouri, Columbia. The $\mathrm{SiO}_{2}$ content was determined by wet chemistry from the laboratory of M/S B.P. Gupta and Sons, Calcutta. Standard samples for INAA have been prepared from well-known standard reference materials, e.g., SRM-1633a Fly Ash, SRM-688 Basalt, and
SRM-278 obsidian rock. Some of the SRM materials were used as standards, and others were used for quality control.

Seven samples of sulfide-mineralized breccia zone and its adjacent rocks have been analyzed for noble metals and few other trace elements by the ICP-MS technique in the laboratory of the National Geophysical Research Institute, Hyderabad, India. No pre-concentration was carried out for this analysis. The sample preparation and ICP-MS technique were after Balaram et al. (1997). The powdered samples and the matching geo-standards (GSJ-Japan, CCRMP-Canada) were dissolved by $\mathrm{HF}, \mathrm{HNO}_{3}$ and $\mathrm{HClO}_{3}$ in different steps and through repeated heating until clear solutions were obtained. Special digestion was used for chromite-rich samples. The instrument used was a Plasma Quad PQ1 (Fisson Instruments, U.K.) controlled by an IBM PCXT microcomputer and associated software. The ion-detection and data-acquisition systems consist of a Channeltron Electron Multiplier (CEM) and a multichannel analyzer (Tracor Northern). Rhodium was taken as the internal standard for noble-metal analysis, whereas both $\mathrm{Rh}$ and $\mathrm{Bi}$ were used as internal standards for other trace-element analyses. For noble metals, the international standards used are SARM-7, which is a platinum ore (South African Bureau of Standards, SABs), CH1 copper-silver-gold-bearing sulfide ore typical of the Campbell-Chibougamau mine of Chibougamau, Quebec, and Matte PTM1 produced from the Sudbury ore. Four sulfide-bearing samples of the breccia zone were analyzed by INAA and AAS for noble metals after a $\mathrm{Pb}$-button fire assay. The $\mathrm{Pb}$-button fire assay was adopted following the standard method of Hafty et al. (1977). Another five samples have been analyzed for noble metals by RNAA in the Analytical Chemistry Laboratory of the Bhabha Atomic Research Center (BARC), Trombay, India. Among these, three samples are sulfide-rich and selected from the breccia zone, and the other two were taken from the massive chromitite band of Durga and Laxmi 2 lode. An ionexchange method was the pre-concentration technique for RNAA, and the procedure followed that of Kumar et al. (1993). 